\title{
QUARTZ MELT RATE FURNACE EVALUATION USING SLUDGE BATCH 3 FEED
}

M. E. Stone

M. A. Baich

R. E. Eibling

A. R. Marinik

D. H. Miller

September 2004

Immobilization Technology Section Savannah River National Laboratory Aiken, SC 29808 
This document was prepared in conjunction with work accomplished under Contract No. DE-AC09-96SR18500 with the U. S. Department of Energy.

\section{DISCLAIMER}

This report was prepared as an account of work sponsored by an agency of the United States Government. Neither the United States Government nor any agency thereof, nor any of their employees, makes any warranty, express or implied, or assumes any legal liability or responsibility for the accuracy, completeness, or usefulness of any information, apparatus, product or process disclosed, or represents that its use would not infringe privately owned rights. Reference herein to any specific commercial product, process or service by trade name, trademark, manufacturer, or otherwise does not necessarily constitute or imply its endorsement, recommendation, or favoring by the United States Government or any agency thereof. The views and opinions of authors expressed herein do not necessarily state or reflect those of the United States Government or any agency thereof.

This report has been reproduced directly from the best available copy.

Available for sale to the public, in paper, from: U.S. Department of Commerce, National Technical Information Service, 5285 Port Royal Road, Springfield, VA 22161, phone: (800) 553-6847, fax: (703) 605-6900

email: orders@ntis.fedworld.gov

online ordering: http://www.ntis.gov/help/index.asp

Available electronically at http://www.osti.gov/bridge

Available for a processing fee to U.S. Department of Energy and its contractors, in paper, from: U.S. Department of Energy, Office of Scientific and Technical Information, P.O. Box 62, Oak Ridge, TN 37831-0062,

phone: (865)576-8401,

fax: (865)576-5728

email: $\underline{\text { reports@ adonis.osti.gov }}$ 
WSRC-TR-2004-00464

Revision 0

Key Words: Melt Rate, DWPF, Offgas Analysis, Hydrogen

Retention: Permanent

\section{QUARTZ MELT RATE FURNACE EVALUATION USING SLUDGE BATCH 3 FEED}

M. E. Stone

M. A. Baich

R. E. Eibling

A. R. Marinik

D. H. Miller

September 2004

Immobilization Technology Section

Savannah River National Laboratory

Aiken, SC 29808 
This page was intentionally left blank 


\section{EXECUTIVE SUMMARY}

The Quartz Melt Rate Furnace (QMRF) was developed to study the melt rate and offgas composition of simulated Defense Waste Processing Facility (DWPF) melter feed. The objective of this testing was to evaluate whether the apparatus could be used to study the offgas chemistry of melting batches and perform small-scale slurry-fed melt rate tests.

The furnace was tested in three different configurations: a dry-fed test with offgas analysis, a slurry-fed test without offgas analysis, and a slurry-fed test with offgas analysis. During the dry-fed test, offgas composition was successfully measured throughout the run and total offgas flow was calculated from the helium tracer concentration. During the slurry-feeding tests without offgas analysis, the furnace exhibited stable feeding behavior with no problems with feed tube pluggage. Feeding behavior was utilized to measure the melt rate of Sludge Batch 3 with Frit 320 and with Frit 418. Both frits had approximately the same melt rate during the tests based on amount of melter feed added per minute. During the slurry-fed test with offgas analysis, spikes in the data prevented overall offgas flow analysis from the helium tracer, but the ratio of different offgas species allowed the composition data to be compared between runs.

Minor improvements were identified that would enhance the performance of the furnace and further testing should be performed to optimize the performance of the apparatus. These tests should focus on increasing the stability of offgas composition data by providing more surge capacity in the offgas system, determining the sensitivity of the furnace to melt rate during slurry-fed tests and refining the lid heat power to optimize melt rate measurements, and to develop the capability to utilize the system with radioactive feeds. 
TABLE OF CONTENTS

EXECUTIVE SUMMARY

iv

LIST OF FIGURES

vi

LIST OF TABLES

vi

LIST OF ACRONYMS

1.0 INTRODUCTION AND BACKGROUND

vii

2.0 EXPERIMENTAL METHODS

2.1 Apparatus

2.2 Initial Dry Fed Run

2.2.1 Offgas Analysis - GC Data

2.2.2 Offgas Analysis: GC/MS Data

2.3 Feed System Tests

2.3.1 Slurry-Feeding Operation

2.3.2 Initial Slurry-Feed System Test - No Lid Heat

2.3.3 Second Feed System Test - Lid Heat Added

2.4 Offgas Analysis Runs

2.4.1 Baseline Run with Offgas Analysis

2.4.2 Low Redox Run with Offgas Analysis

2.4.3 High Acid Run with Offgas Analysis

3.0 RESULTS

3.1 Temperature Data from Offgas Analysis Runs

3.2 Pressure Data from Offgas Analysis Runs

3.3 Offgas Composition from Offgas Analysis Runs

3.3.1 Overall Summary of Offgas Composition Measurements 16

3.4 Melt Rate Tests

4.0 CONCLUSIONS

5.0 RECOMMENDATIONS 19

6.0 REFERENCES

Appendix A. Diagrams of QMRF Configurations

Appendix B. Temperature Data from QMRF Runs

Appendix C. Gas Chromatograph Data from QMRF Runs

Appendix D. Feed Rate Charts for Melt Rate Tests 


\section{LIST OF FIGURES}

Figure 1. Top of Quartz Beaker during Initial Run .......................................................... 5

Figure 2. Vapor Space Temperature during Initial Feed Tube Test. ......................................... 7

Figure 3. Vapor Space Temperature during Feed Tube Test with Lid Heaters........................ 8

Figure 4. Vapor Space Temperature Profile during Low Redox Run.................................. 10

Figure 5. Vapor Space Temperature Comparison (Manual data only).................................... 10

Figure 6. Pressure Profile during High Acid Run.................................................................. 11

Figure 7. Ratio of Hydrogen to Carbon Dioxide during QMRF Runs .................................. 13

Figure 8. Oxygen to Nitrogen Ratio from QMRF Runs..................................................... 14

Figure 9. Nitrous Oxide to Hydrogen Ratio during Dry-Fed Tests ..................................... 15

Figure 10. Calculated Offgas Flowrates. ..................................................................... 15

\section{LIST OF TABLES}

Table 1. Calculated Offgas Composition from Initial Dry-Fed Tests ...................................... 4

Table 2. Offgas samples and GC/MS Analysis during Initial QMRF Run. ............................ 5

Table 3. Melt Rate Calculations for Frit 418 and Frit 320 Runs .......................................... 17 


\section{LIST OF ACRONYMS}

$\begin{array}{ll}\text { ACTL } & \text { Aiken County Technology Laboratory } \\ \text { QMRF } & \text { Quartz Melt Rate Furnace } \\ \text { DWPF } & \text { Defense Waste Processing Facility } \\ \text { SRNL } & \text { Savannah River National Laboratory } \\ \text { MRF } & \text { Melt Rate Furnace } \\ \text { SMRF } & \text { Slurry-Fed Melt Rate Furnace } \\ \text { GC } & \text { Gas Chromatograph } \\ \text { GC/MS } & \text { Gas Chromatograph/Mass Spectrometer }\end{array}$




\subsection{INTRODUCTION AND BACKGROUND}

The Savannah River National Laboratory (SRNL) personnel have successfully developed and utilized two furnaces, the Melt Rate Furnace (MRF) and the Slurry-fed Melt Rate Furnace (SMRF), to evaluate the melt rate of simulated Defense Waste Processing Facility (DWPF) feed. Melt rate tests with the two furnaces generally show good agreement in the trends noted during testing which also have been confirmed in the DWPF melter. For example, tests in the MRF and the SMRF indicate that increased alkali content increases melt rate and DWPF processing has indicated that melt rate is improved at higher alkali contents.

The MRF determines the melt rate of dried feed by heating a beaker of feed from the bottom for a specified length of time and measuring the amount of glass formed. This test has been utilized as a screening tool for initial testing of various processing options since it utilizes a small amount of material and can be performed quickly. The cost effectiveness of the MRF has resulted in the use of this furnace for the majority of melt rate testing. The MRF is limited in three ways: 1) the dry-fed test does not replicate the slurry-fed DWPF melter in some aspects and 2) the melt rate is measured only at the point in time that the beaker is removed from the furnace and quenched and 3) the MRF test results do not match the SMRF results when feed chemistry changes are made that do not impact the final glass composition.

The Slurry-Fed Melt Rate Furnace (SMRF) is larger in size ( 8 " diameter vs. 4.125") than the MRF. The SMRF operates with semi-continuous slurry-feeding and glass pouring and determines melt rate by measuring the glass pour rate during operation. The furnace is operated by feeding a specified amount into the melter and monitoring the vapor space temperature. When the vapor space temperature recovers from the temperature decrease caused by the feed addition, the feed cycle is repeated. The operating mode is designed to match the conditions in the DWPF process as closely as practical. Compared to the MRF, a much larger amount of feed is required and the duration of the run is much longer in the SMRF, considerably increasing the cost of each run. The SMRF is typically utilized to verify the trends noted during MRF testing.

The MRF and SMRF were not designed to allow the offgas from the melting batch to be captured or analyzed. The composition of the offgas can provide insight into the reactions that occur as the batch melts. Also, differences were noted in the measured melt rates in the two furnaces when feed chemistry changes that do not impact the glass composition (such as acid addition changes) were tested [1]. The MRF results were likely invalid for these tests since the feed is dried prior to testing. The Quartz Melt Rate Furnace (QMRF) was designed to evaluate offgas from the melting batch and to provide a cost-effective screening tool for slurry-fed tests when feed chemistry changes are made. The QMRF could replace the MRF for all screening tests if the melt rate results indicate that the QMRF is more effective than the MRF from the basis of cost and schedule as well as sensitivity to melt rate and agreement with SMRF results.

This work documented in this report was performed as scoping work to develop the QMRF as a tool that can be utilized to evaluate methods to improve the melt rate of the DWPF $[2,3]$. 
WSRC-TR-2004-00464

Revision 0

This page intentionally left blank. 


\subsection{EXPERIMENTAL METHODS}

\subsection{Apparatus}

The QMRF utilized the same top loading furnace as the MRF, the Blue M model CF56822C. The $1200 \mathrm{ml}$ stainless steel beaker with an insulating board cover utilized in the MRF was replaced with a quartz beaker as shown in Figures A-1 and A-4. Tests of the feed system and melt rate tests were conducted with the stainless steel beakers, as shown in Figure A-2 and A-3. The top of the quartz beaker contained four ground glass joints to allow an offgas system, air purge, feed tube, and thermocouple to be installed. The same insulating sleeve utilized on the MRF was used to insulate the sides of the QMRF beaker, but the top of the sleeve was modified to allow installation of the vapor space heaters.

The offgas system, when installed, consisted of an air purge, a condenser, dilution air mixing vessel, and a portable high speed Gas Chromatograph (GC). A manometer and a pressure gauge were installed on the air purge inlet to provide a blowout path in case of offgas line pluggage and to monitor the pressure in the beaker during the run. The temperatures of the beaker vapor space and the condenser outlet were measured during the tests. Condensate from the run collected in the dilution air mixing vessel. Dilution air and a helium tracer were added to the mixing vessel and blended with the beaker offgas. A syringe port on the mixing vessel allowed offgas samples to be extracted for injection in a Gas Chromatograph/Mass Spectrometer (GC/MS).

The feed system for the QMRF consisted of a feed tank, weigh scale, mixer, peristaltic pump and water cooled feed tube. The pump was set to dispense $10 \mathrm{ml}$ at a time and was triggered via a remote switch. An optical tachometer was utilized to measure the speed of the mixer during the tests.

\subsection{Initial Dry Fed Run}

The objective of the initial run was to shake down the unit and determine any problem areas prior to additional testing [4,5]. Approximately 1200 grams of SME product ${ }^{1}$ were dried and charged to the quartz beaker. The quartz beaker was placed into the furnace and the offgas system was assembled as shown in Figure A-1 of Appendix A. The furnace was then ramped as rapidly as possible to $1150^{\circ}$ Celsius and the offgas response was measured. Two gas chromatographs were used to continuously measure the concentration of hydrogen, carbon dioxide, oxygen, and helium in the offgas. A syringe was utilized to pull offgas samples for analysis in the GC/MS instrument located in lab 136 of ACTL. The GC/MS was utilized to analyze for $\mathrm{NO}$ and sulfur dioxide.

\footnotetext{
${ }^{1}$ SME product was obtained from melt rate studies. The batch tested was SB2/3 blended feed at $135 \%$ acid stoichiometry and Frit 418 at a waste loading of $35 \%$. This material was rejected for other melt rate tests because the Frit 418 utilized contained a large number of fines. Although the fines in the frit may affect the melt rate of the feed, the composition of the offgas is determined by the sludge component; therefore, this feed was considered acceptable for this initial test.
} 
The initial air purge to the beaker was set at $50 \mathrm{ml} / \mathrm{min}$, but was increased to $90 \mathrm{ml} / \mathrm{min}$ during the run due to the amount of hydrogen evolved during the test. Helium purge rate was constant at $25 \mathrm{ml} / \mathrm{min}$ and dilution air to the mixing vessel was constant at $2000 \mathrm{ml} / \mathrm{min}$. Furnace heat up from ambient temperature to $1150^{\circ} \mathrm{C}$ required approximately 40 minutes while conversion of the beaker contents to glass required approximately 50 additional minutes, as shown in Figure B-1 of Appendix B. A slight bed expansion was seen in the beaker as the run progressed. The bed expansion collapsed at a run time of 65 minutes and caused a pressure spike that blew out the beaker manometer and the temperature of the beaker vapor space rapidly increased. A significant amount of back pressure from the $1 / 4$ " diameter offgas line occurred during the run, with a maximum pressure of 6 to $7 \mathrm{~cm}$ of water column reached at the peak of melter offgas emissions.

\subsubsection{Offgas Analysis - GC Data}

Two gas chromatographs (GCs) were utilized to measure the offgas composition during the tests. The GCs were configured to automatically pull a sample from the offgas stream on a two minute cycle and the sampling of the GCs was staggered so that an offgas sample was analyzed each minute during the run. The ten liter vessel averaged the offgas composition over approximately twenty minutes; therefore an assessment of the melt rate using the offgas data was not possible. Overall composition trends for the offgas are shown graphically in Figure C-1. The chart shows spikes in the data at the time of the batch collapse followed by a decline in melter offgas generation. The data points at the end of the each chart represent the post test calibration of the GCs.

The amount of helium in the offgas stream was utilized to calculate the total amount of offgas flow. By subtracting the amount of air purge streams, the total amount of offgas from the melting batch was determined. The composition of the offgas stream along with the composition of the purge streams was then utilized to calculate the composition of the offgas from the batch. The composition of the offgas was fairly consistent during the middle portion of the run, except for the hydrogen composition. The compositions during this portion of the run were averaged to obtain the "steady-state" offgas composition from the batch. As shown in Table 1, nitrogen and carbon dioxide were the two largest components of the melter offgas. The offgas was brown in color, as shown in Figure 1. The only offgas component expected to be brown is $\mathrm{NO}_{\mathrm{x}}$, therefore it is likely that the bulk of the unmeasured offgas components are $\mathrm{NO}$ and $\mathrm{NO}_{2}$ with some amount of $\mathrm{CO}$. Water vapor was condensed prior to offgas measurement and is excluded from the offgas composition.

Table 1. Calculated Offgas Composition from Initial Dry-Fed Tests

\begin{tabular}{|c|c|c|c|c|c|c|}
\hline $\begin{array}{c}\text { Total } \\
\text { Offgas } \\
\text { Flow }\end{array}$ & $\begin{array}{c}\mathrm{N}_{2} \mathrm{O} \\
\text { Emitted }\end{array}$ & $\begin{array}{c}\mathrm{H}_{2} \\
\text { Emitted }\end{array}$ & $\begin{array}{c}\mathrm{CO}_{2} \\
\text { Emitted }\end{array}$ & $\begin{array}{c}\mathrm{N}_{2} \\
\text { Emitted }\end{array}$ & $\begin{array}{c}\mathrm{O}_{2} \\
\text { Emitted }\end{array}$ & $\begin{array}{c}\text { Unmeasured } \\
\text { Components }\end{array}$ \\
\hline $\mathrm{ml} / \mathrm{min}$ & $\mathrm{ml} / \mathrm{min}$ & $\mathrm{ml} / \mathrm{min}$ & $\mathrm{ml} / \mathrm{min}$ & $\mathrm{ml} / \mathrm{min}$ & $\mathrm{ml} / \mathrm{min}$ & $\mathrm{ml} / \mathrm{min}$ \\
\hline 1657 & 12.19 & 48.77 & 639.45 & 655 & 90.09 & 211.5 \\
\hline & $\begin{array}{c}\text { Volume } \\
\%\end{array}$ & $\begin{array}{c}\text { Volume } \\
\%\end{array}$ & $\begin{array}{c}\text { Volume } \\
\%\end{array}$ & $\begin{array}{c}\text { Volume } \\
\%\end{array}$ & $\begin{array}{c}\text { Volume } \\
\%\end{array}$ & $\begin{array}{c}\text { Volume } \\
\%\end{array}$ \\
\hline & 0.74 & 2.94 & 38.59 & 39.53 & 5.44 & 12.76 \\
\hline
\end{tabular}




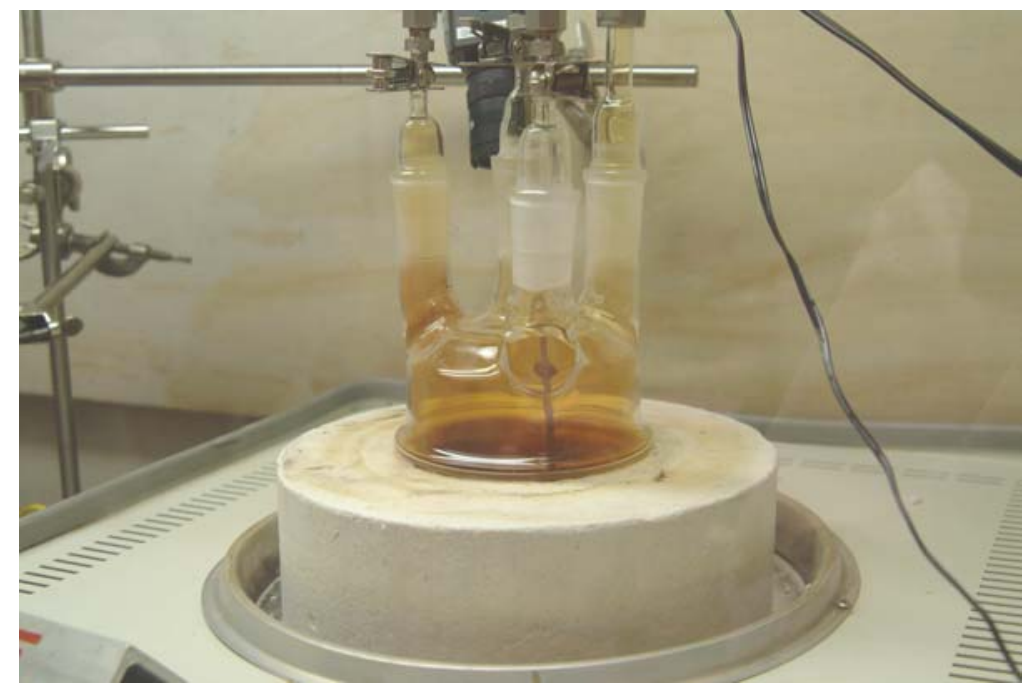

Figure 1. Top of Quartz Beaker during Initial Run

\subsubsection{Offgas Analysis: GC/MS Data}

A gas chromatograph / mass spectrometer (GC/MS) was utilized to analyze six samples pulled from the offgas stream. The samples were taken by inserting a syringe into the mixing vessel and pulling a $100 \mu \mathrm{L}$ gas sample. The gas sample was then taken to the GC/MS and injected. The species identified in each sample, excluding air, and the time the sample was pulled is shown in Table 2. The GC/MS was not calibrated prior to the run due to lack of a suitable calibration gas, therefore the amounts of each compound could not be obtained from the data.

Table 2. Offgas samples and GC/MS Analysis during Initial QMRF Run.

\begin{tabular}{|c|c|c|c|}
\hline Sample \# & $\begin{array}{c}\text { Sample } \\
\text { Time }\end{array}$ & $\begin{array}{c}\text { Run Time } \\
\text { (Minutes) }\end{array}$ & Species Identified \\
\hline QMRF - 1 & 1019 & 1.0 & $\mathrm{CO}_{2}, \mathrm{H}_{2} \mathrm{O}, \mathrm{NO}$, fluorotrimethylsilane \\
\hline QMRF - 2 & 1034 & 16 & $\mathrm{CO}_{2}, \mathrm{H}_{2} \mathrm{O}, \mathrm{NO}$, fluorotrimethylsilane \\
\hline QMRF - 3 & 1048 & 30 & $\mathrm{CO}_{2}, \mathrm{H}_{2} \mathrm{O}, \mathrm{NO}$, fluorotrimethylsilane \\
\hline QMRF -4 & 1057 & 39 & $\mathrm{CO}_{2}, \mathrm{H}_{2} \mathrm{O}, \mathrm{NO}$, fluorotrimethylsilane \\
\hline QMRF -5 & 1113 & 55 & $\mathrm{CO}_{2}, \mathrm{H}_{2} \mathrm{O}, \mathrm{NO}$, fluorotrimethylsilane \\
\hline QMRF -6 & 1128 & 70 & $\mathrm{CO}_{2}, \mathrm{H}_{2} \mathrm{O}, \mathrm{NO}$, fluorotrimethylsilane \\
\hline
\end{tabular}

No peaks were identified for $\mathrm{NO}_{\mathrm{x}}$ or $\mathrm{SO}_{2}$, but these species were likely absorbed on the GC column and did not make it to the detector. The fluoride species detected was likely the result of hydrofluoric or fluorine gas species reacting with the GC column.

Based on the results of these tests, the mixing vessel was reduced from 10 liters to two liters, the apparatus adjusted so that the offgas line always sloped away from the beaker, and the number of GCs utilized during the testing was reduced from two to one. In addition, the diameter of the offgas line was increased from $1 / 4$ " to $3 / 8$ " to reduce the backpressure on the beaker during the tests. 


\subsection{Feed System Tests}

\subsubsection{Slurry-Feeding Operation}

Two tests were conducted to evaluate the slurry-feeding characteristics of the QMRF and to determine the acceptability of the quartz feed tube. Both tests were conducted in stainless steel, open-top beakers without an offgas system. The first test was conducted without lid heaters, as shown in Figure A-2. The second test was conducted after lid heaters were added to the system, as shown in Figure A-3. These tests utilized the same feed as the Initial Dry-Fed test.

Each run began with approximately 300 grams of glass cullet in the quartz beaker. The cullet was obtained from the glass drained from the SMRF during baseline Frit 418 tests [6]. The furnace and beaker were assembled as described above and heated to $1150^{\circ} \mathrm{C}$. The glass cullet melted during the heat up and provided an initial glass pool prior to slurry-feeding.

The lid heaters were ramped to 600 watts during the furnace heat up and held at a constant 600 watts during slurry feeding. The air purge to the beaker was approximately $200 \mathrm{ml} / \mathrm{min}$ while the dilution air to the mixing vessel was $2000 \mathrm{ml} / \mathrm{min}$ and the helium addition was 10 to 25 $\mathrm{ml} / \mathrm{min}$. Feeding was initiated after the furnace reached $1150^{\circ} \mathrm{C}$ and the beaker vapor space reached $750^{\circ} \mathrm{C}$ or temperature specified by researcher. Approximately $10 \mathrm{ml}$ of feed was added during each feed cycle at a feed rate of $100 \mathrm{ml} / \mathrm{min}$ and lowered the vapor space temperature by varying amounts depending on the position of the thermocouple in the beaker. When the vapor space temperature recovered to $750^{\circ} \mathrm{C}$ or temperature specified by researcher, the next feed cycle was initiated.

\subsubsection{Initial Slurry-Feed System Test - No Lid Heat}

During the first test [7], the feed pump was set to deliver $10 \mathrm{ml}$ of feed at $100 \mathrm{ml} / \mathrm{min}$ each time the pump was triggered. An initial charge of 300 grams of cullet was placed in the beaker prior to heat up to provide a glass pool at the start of the test. The furnace was ramped to temperature and feeding commenced. The vapor space temperature took approximately 7 minutes to recover after each feed cycle, as shown in Figure 2 and B-2. Based on the feed rates of the SMRF and the relative sizes of the two melter vessels, the feed rate of $1.4 \mathrm{ml} / \mathrm{min}$ without the lid heaters was significantly lower than the SMRF and was judged to be too low, therefore, modifications were made to add lid heaters to the beaker. 


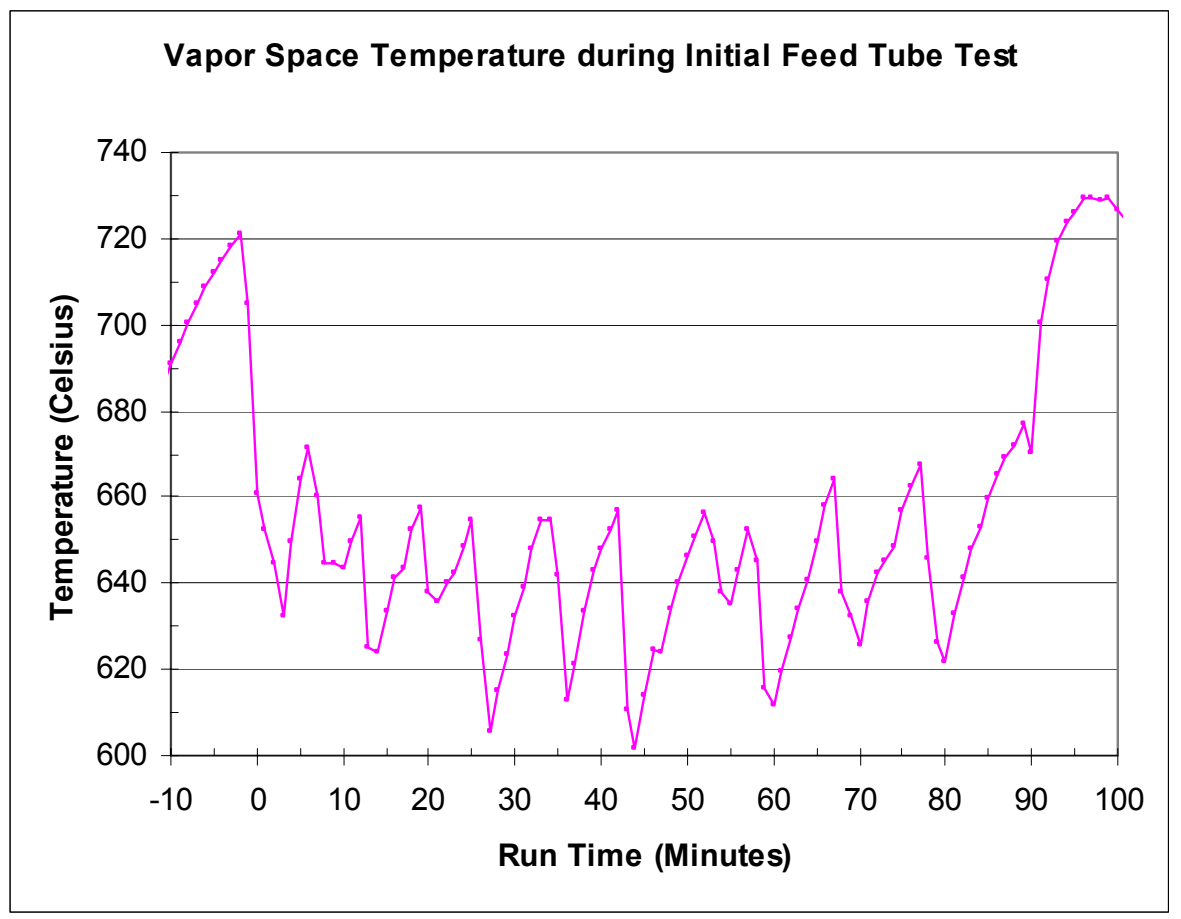

Figure 2. Vapor Space Temperature during Initial Feed Tube Test.

\subsubsection{Second Feed System Test - Lid Heat Added}

Two $600 \mathrm{~W}$ lid heaters from Thermcraft were added to the insulating sleeve prior to the second feed system test [8]. The furnace was then reassembled and a test was performed that was identical to the first test except for the lid heat. The feed rate $(\sim 5 \mathrm{ml} / \mathrm{min})$ during the second test was significantly increased with the interval between feed cycles reduced to 2 minutes, as shown in Figure 3 and B-3. 


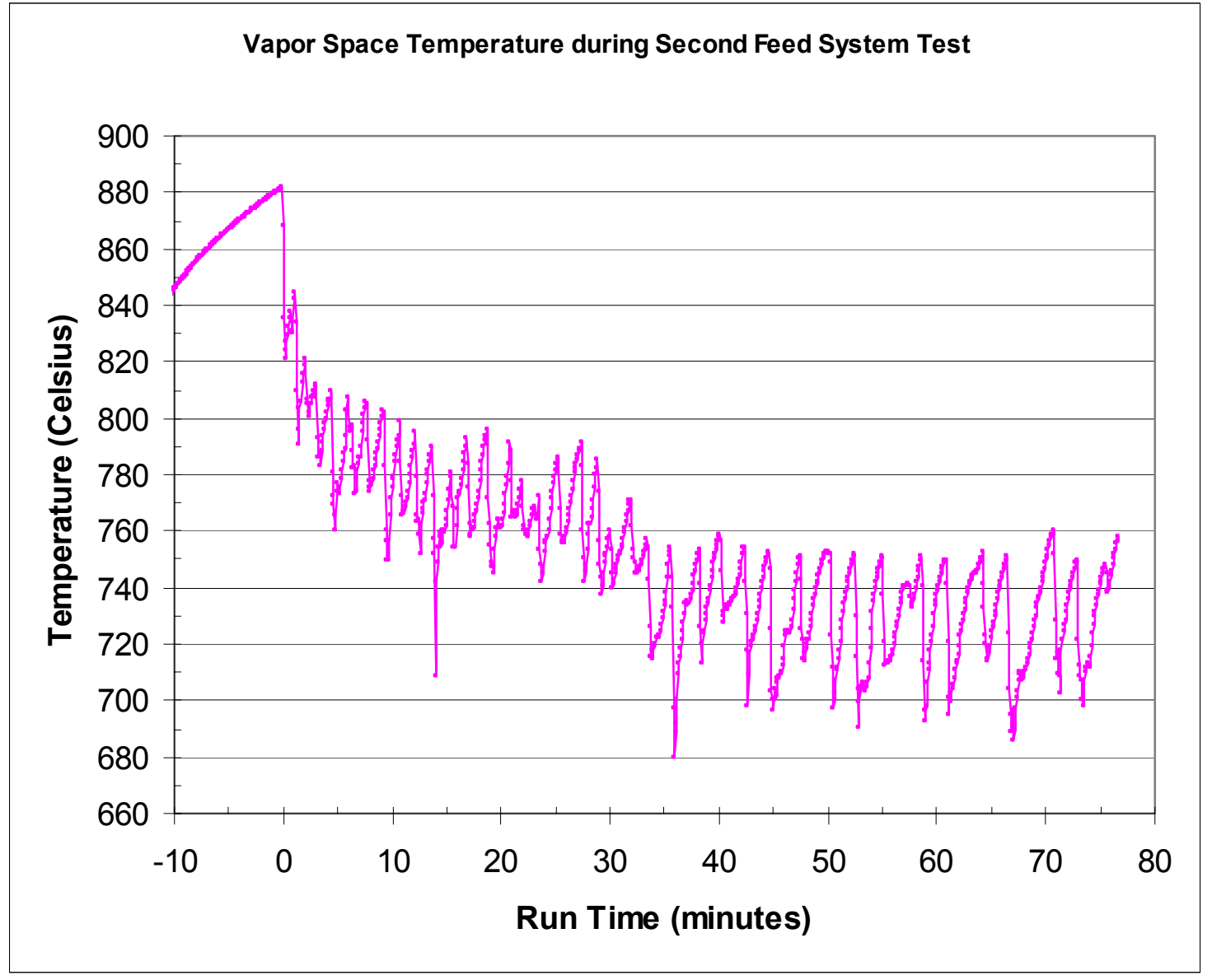

Figure 3. Vapor Space Temperature during Feed Tube Test with Lid Heaters.

\subsection{Offgas Analysis Runs}

\subsubsection{Baseline Run with Offgas Analysis}

This run was conducted with simulated SB2/3 melter feed utilizing Frit 418 with a solids concentration of $45 \%$ and a waste loading of $35 \%$ to provide a baseline for comparisons [9]. The acid stoichiometry during the SRAT cycle was $155 \%$ and the redox target was $0.2 \mathrm{Fe}^{+2} / \Sigma \mathrm{Fe}$ [10]. The vapor space temperature did not drop significantly during feed additions due to differences in the type of beaker and location of the vapor space thermocouple, as shown in Figure B-4; therefore, the feed cycle was operated using a two minute delay between feed additions. Over time, the vapor space temperature decreased; therefore, additions were adjusted to every 2.5 minutes. The initial feed rate was approximately 7 grams per minute $(\sim 5 \mathrm{ml} / \mathrm{min})$ while the feed rate during the latter portion of the run was approximately 4 grams/minute. The computer used for data collection from the melter pressure meter locked up several times during the run, resulting in gaps in the data. Similar computer problems led to the loss of the automatic temperature data from this run. Offgas analysis and temperature data for this run is discussed in section 3.0. 


\subsubsection{Low Redox Run with Offgas Analysis}

The purpose of this test was to assess lower redox as compared to the baseline run. All other run conditions held constant to the extent possible [11]. The low redox run was conducted with simulated SB2/3 melter feed utilizing Frit 418 with a solids concentration of $45 \%$. The acid stoichiometry during the SRAT cycle was $155 \%$ and the redox target was $0.0 \mathrm{Fe}^{+2} / \Sigma \mathrm{Fe}[12]$. The feed cycle was operated in the same manner as the baseline run with time delays between feed cycles. The feed rate was approximately four grams per minute for this run. The pressure data contains gaps due to the same computer problems as the baseline run. Offgas analysis and temperature data for this run is discussed in section 3.0

\subsubsection{High Acid Run with Offgas Analysis}

The purpose of this test was to assess higher acid stoichiometry as compared to the baseline run. All other run conditions held constant to the extent possible. The high acid run was conducted with simulated SB2/3 melter feed utilizing Frit 418 with a solids concentration of $45 \%$ [13]. The acid stoichiometry during the SRAT cycle was $185 \%$ and the redox target was $0.2 \mathrm{Fe} / \Sigma \mathrm{Fe}$ [14]. The feed cycle was operated in the same manner as the baseline run with time delays between feed cycles. The feed rate was approximately 7 grams per minute during this run. The pressure data collection problems were resolved, so no gaps exist in the pressure data. The data collection for the temperature meter locked up during the run, therefore only the initial part of the run was recorded. Feed tube pluggage problems led to the run being aborted after only 45 minutes of testing. Offgas analysis and temperature data for this run is discussed in section 3.0

\subsection{RESULTS}

\subsection{Temperature Data from Offgas Analysis Runs}

The temperature data was collected from four locations during the tests: the furnace chamber temperature (manual readings only), the annulus between the vapor space heaters and the beaker, the beaker vapor space, and the offgas condenser exit. Automatic data logging was conducted for the temperature data, but problems with the communications between the temperature instrument and the datalogging computer led to some loss of data requiring the use of the manually recorded data. The vapor space temperature profile for the low redox run is shown in Figure 4 while full temperature profiles for all runs are shown in Appendix B. A comparison of vapor space temperatures during the QMRF runs is shown in Figure 5. 


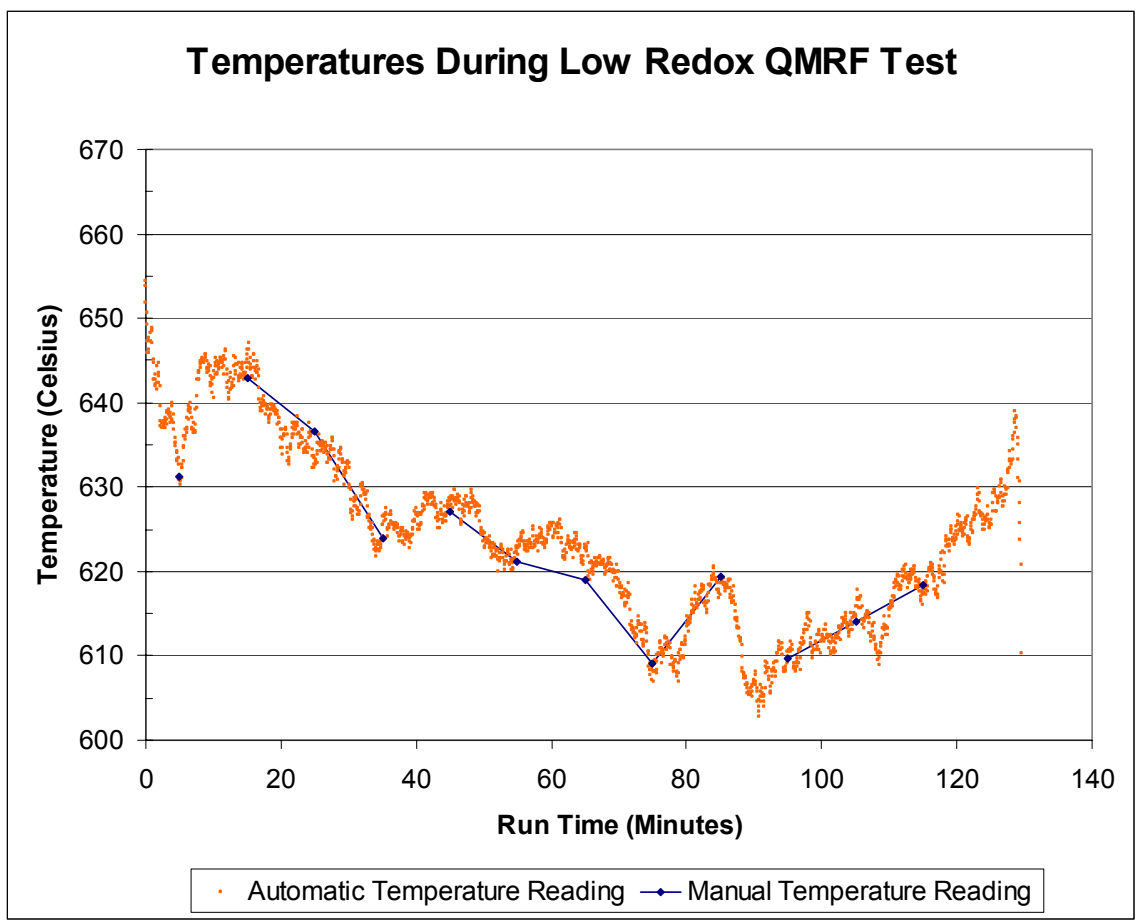

Figure 4. Vapor Space Temperature Profile during Low Redox Run.

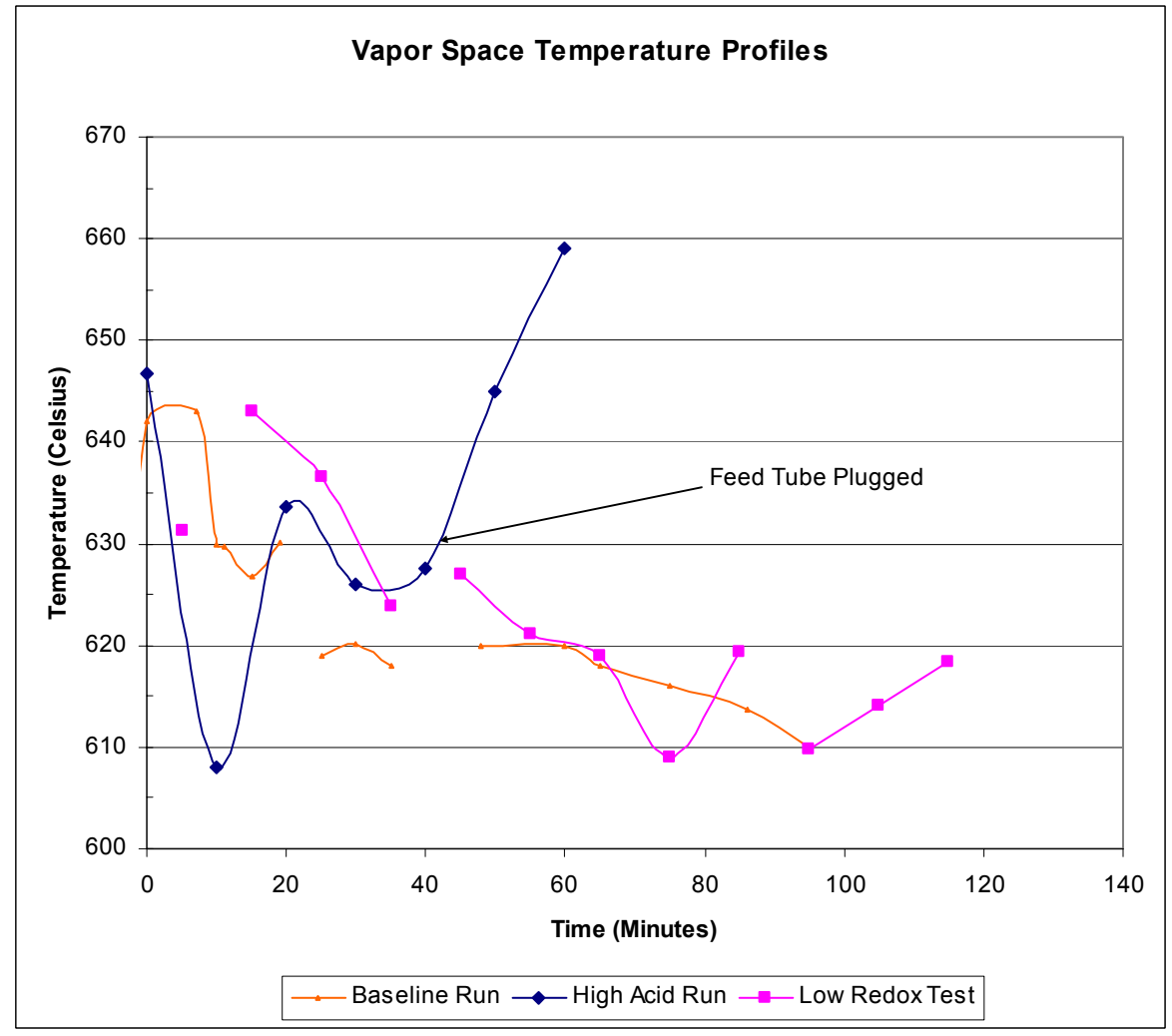

Figure 5. Vapor Space Temperature Comparison (Manual data only). 


\subsection{Pressure Data from Offgas Analysis Runs}

Communication issues with the datalogging computer led to gaps in the pressure data for the baseline run and the low redox run, but the problems were corrected and the pressure data was collected during the entire high acid run. The pressure profile shown in Figure 6 was typical for all runs, based on the data that was collected during the baseline and low redox runs. When no cold cap was present (initial feeding), the pressure surge from the $10 \mathrm{ml}$ feed addition was seen to occur as a large spike in the beaker pressure. As the cold cap formed, the large spike was replaced with broader peaks until the feed addition could not be discerned from the background.

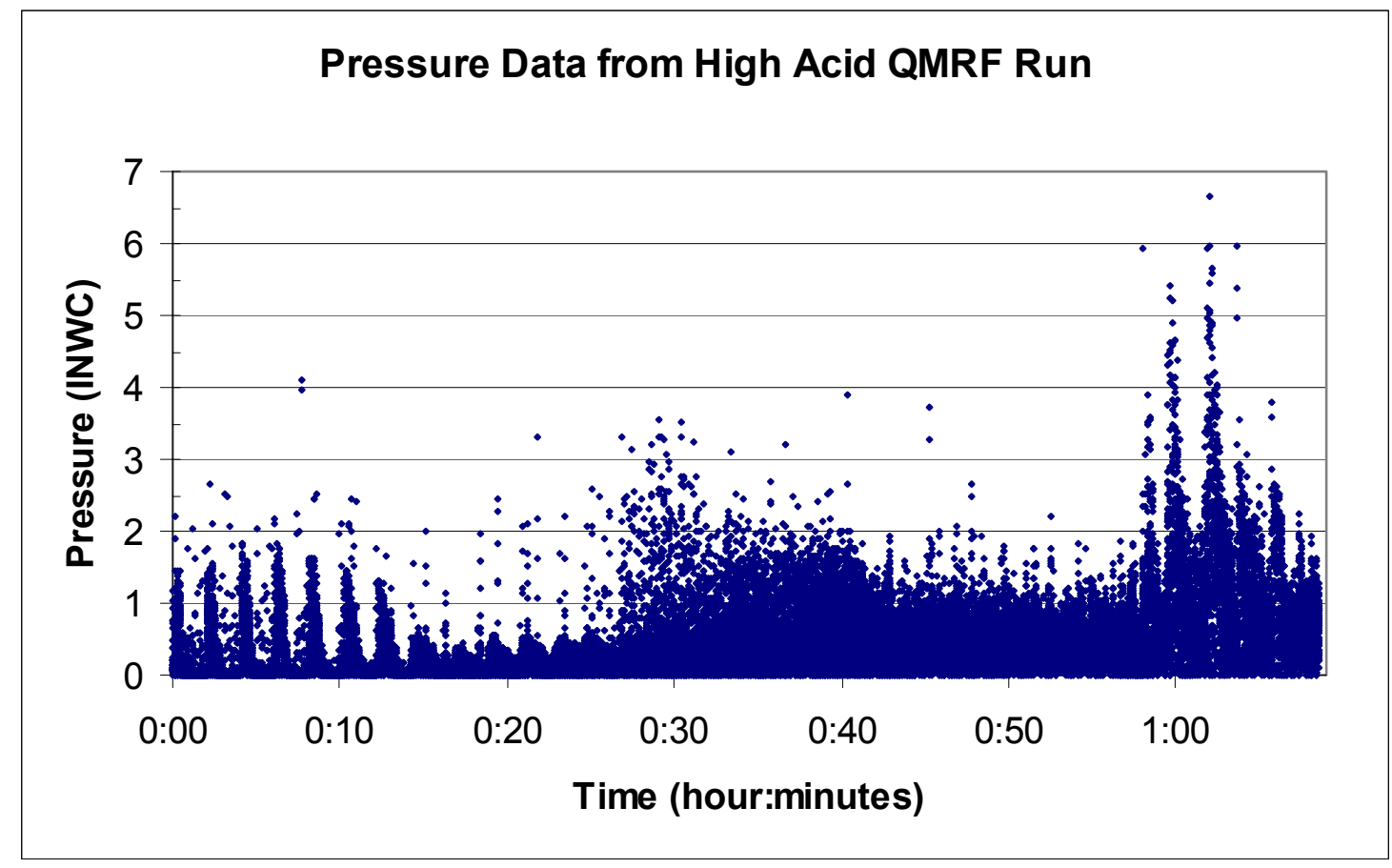

Figure 6. Pressure Profile during High Acid Run.

\subsection{Offgas Composition from Offgas Analysis Runs}

The vitrification of sludge generates offgas from evaporation of water and other volatile components as well as the decomposition of the nitrate, formate, carbonate, and other thermally unstable components. Water is the primary component of the offgas, accounting for approximately $90 \%$ of the offgas flow from the melting batch. The water was condensed from the offgas with a water cooled condenser during the offgas composition tests and was not factored into the calculations for the offgas composition The reactions that occur between the unstable components in the cold cap and vapor space of the melter are numerous and have been modeled by SRNL [15]. The products of these reactions are primarily $\mathrm{CO}_{2}, \mathrm{~N}_{2}, \mathrm{O}_{2}, \mathrm{H}_{2}, \mathrm{NO}_{\mathrm{x}}$, $\mathrm{N}_{2} \mathrm{O}, \mathrm{SO}_{\mathrm{x}}$, and $\mathrm{CO}$.

The concentration of carbon dioxide, helium, hydrogen, nitrogen, nitrous oxide, and oxygen in the offgas from the beaker was measured during the QMRF runs with an Agilent 3000A portable GC with molecular sieve 5A (ten meter length) and PorPlot Q (ten meter length) columns. Agilent's Cerity® software was utilized to analyze the GC data. The results from the tests 
indicate that steady state conditions were not present during the runs, as indicated by the offgas composition charts in Appendix C. The performance of comparisons between the runs is limited by the non-steady state nature of the data, but some trends were noted in the data by comparing the ratios of the different gases.

The hydrogen/carbon dioxide ratio (volume \% basis) was significantly lower for the low redox run than for the two runs at the baseline redox, as shown in Figure 7. Hydrogen/carbon dioxide ratio was similar for the baseline run, the high acid run, and the initial dry fed run. All three of these runs were conducted with a target redox of $0.2 \mathrm{Fe}^{+2} / \Sigma \mathrm{Fe}$, while the low redox run targeted $0.0 \mathrm{Fe}^{+2} / \Sigma \mathrm{Fe}$. The data indicate that more oxidizing feeds increase the combustion of $\mathrm{CO} / \mathrm{H}_{2}$ mixtures to $\mathrm{CO}_{2} / \mathrm{H}_{2} \mathrm{O}$, lowering the ratio of hydrogen to carbon dioxide.

A trend that was also shown in the data was higher hydrogen ratios versus carbon dioxide at the start of the runs. The lack of a cold cap at the start of the run may have been a significant factor in the higher hydrogen ratios. The underlying layers of the cold cap release significant amounts of oxygen which can react with the $\mathrm{CO} / \mathrm{H}_{2}$ mixture to form $\mathrm{CO}_{2} / \mathrm{H}_{2} \mathrm{O}$. The purge rates utilized during the test runs may not have been sufficient to provide oxygen for this reaction, therefore, hydrogen to carbon dioxide ratios at the start of the run may be higher than would be expected for DWPF operation where the purge rate into the melter is significantly higher on a scaled basis than was utilized during these tests.

The drop in the hydrogen to carbon dioxide ratio at approximately 65 minutes for the dry-fed test is the result of the batch collapse that blew out the manometers on the system. The amount of offgas noted from the batch after the collapse was dropped significantly, indicating that the conversion of the batch to oxides was nearly complete at that point. 


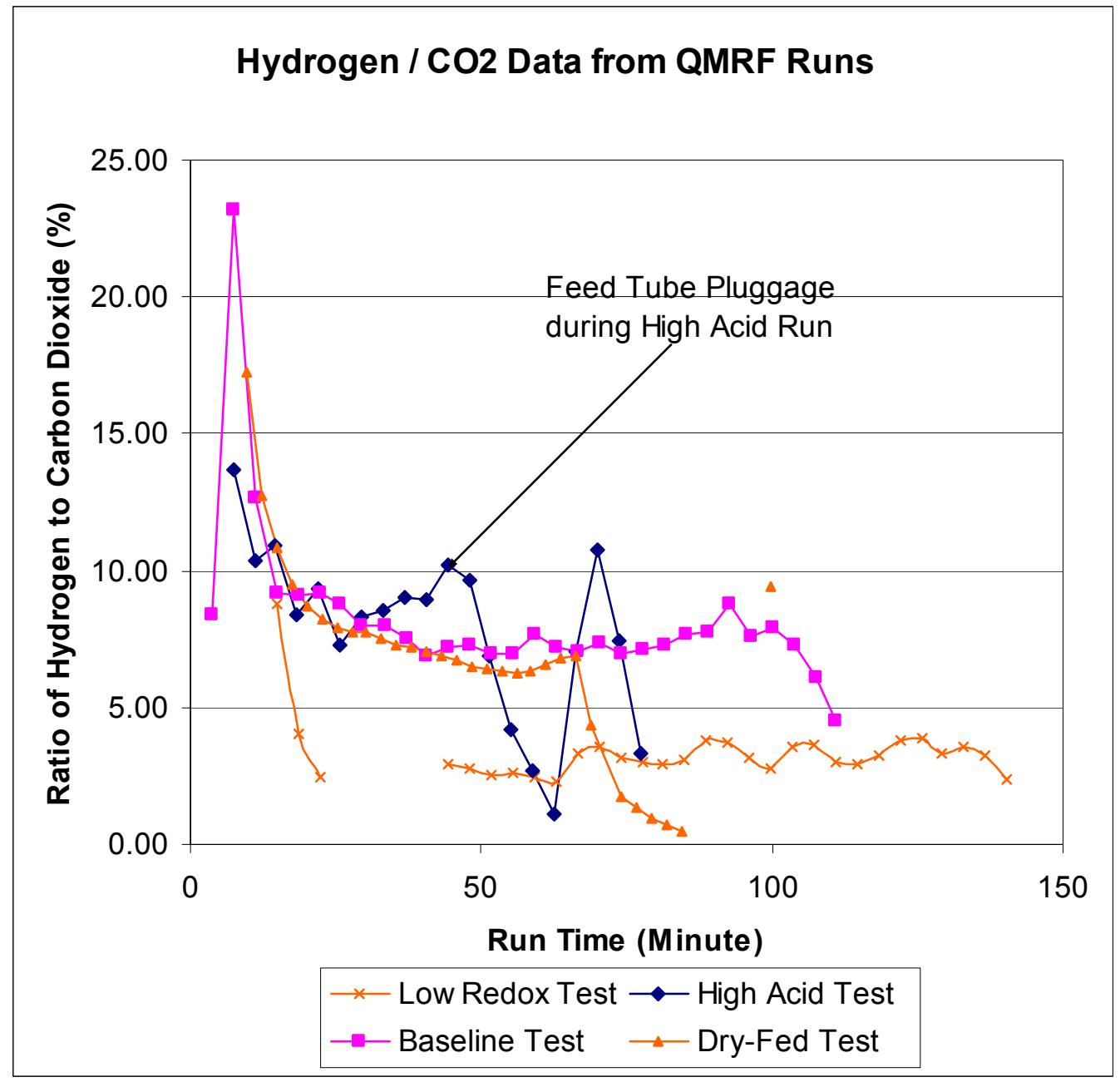

Figure 7. Ratio of Hydrogen to Carbon Dioxide during QMRF Runs

The oxygen to nitrogen ratio was also impacted by the redox of the feed during the tests, as shown in Figure 8. The oxygen to nitrogen ratio varied at the start of the run when air was flowing through the GC, therefore all runs were adjusted to an average of $25 \%$ at the start of the run. As shown in Figure 8, the low redox run had a lower oxygen to nitrogen ratio during the run. As discussed above, the more oxidizing feed likely led to an increase in the combustion of $\mathrm{CO} / \mathrm{H}_{2}$ mixtures to $\mathrm{CO}_{2} / \mathrm{H}_{2} \mathrm{O}$, lowering the ratio of hydrogen to carbon dioxide. This same reaction would lower the amount of oxygen released and lower the $\mathrm{O}_{2} / \mathrm{N}_{2}$ ratio. Additional tests would be required to determine if results for this ratio are within the experimental error of the test method. 


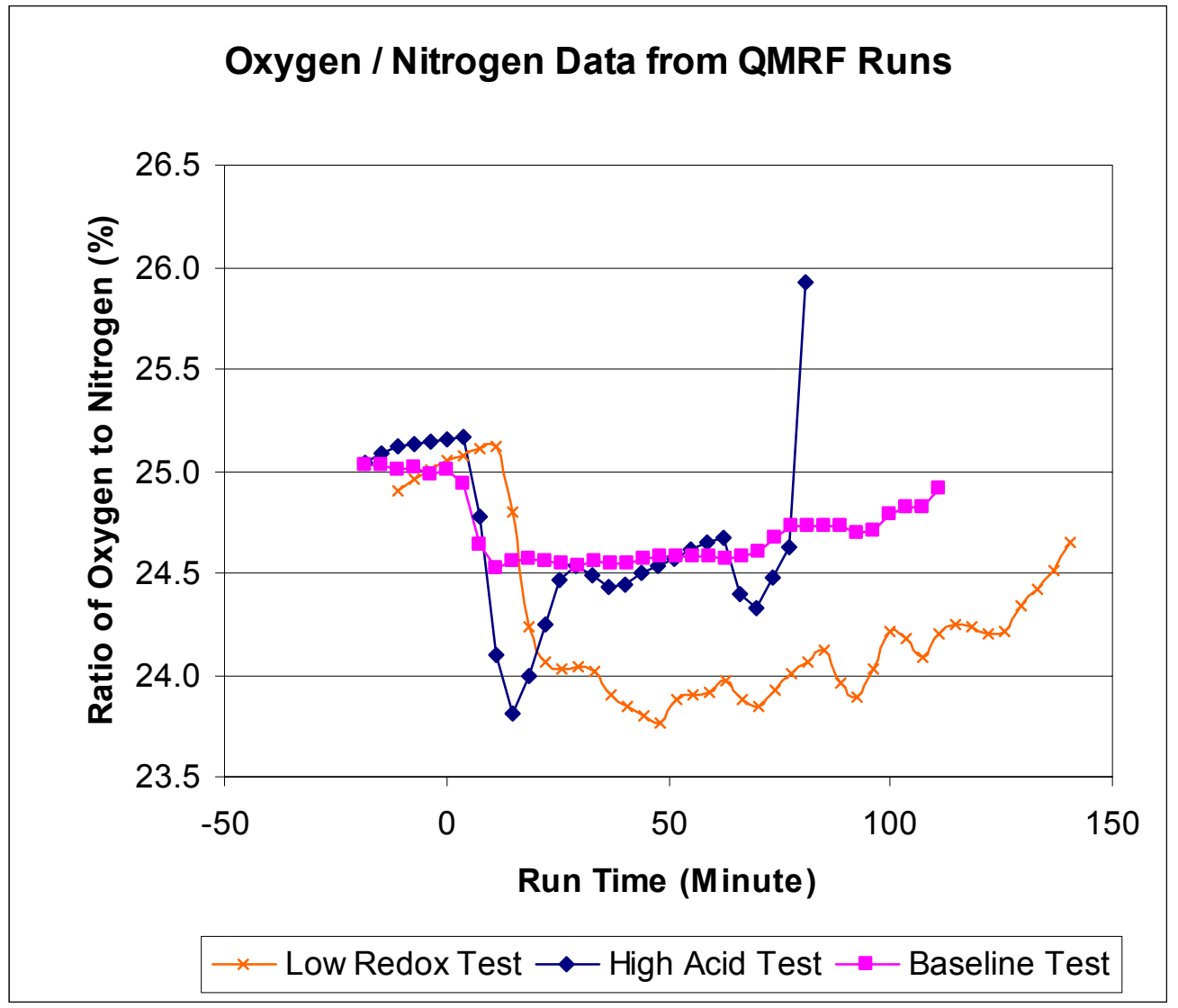

Figure 8. Oxygen to Nitrogen Ratio from QMRF Runs.

The nitrous oxide concentration during the dry-fed test was 50 to $60 \%$ of the hydrogen concentration, as shown in Figure 9. During the slurry-fed tests, the nitrous oxide emission was too low for the GC to pickup, although very small peaks were noted in the location expected for $\mathrm{N}_{2} \mathrm{O}$. The vapor space temperature was significantly higher during the slurry-fed tests, which may have caused nitrogen formation to be favored versus $\mathrm{N}_{2} \mathrm{O}$. The oxygen to nitrogen ratio for the dry-fed test was not used for comparison given the much faster melt rate of the dry feed based on the conversion of the entire 1200 grams of batch material to oxide in approximately 60 minutes versus the slightly less than 500 grams of batch material converted per hour of slurry feeding. The faster melt rate resulted in much lower oxygen to nitrogen ratios than the slurry fed tests. 


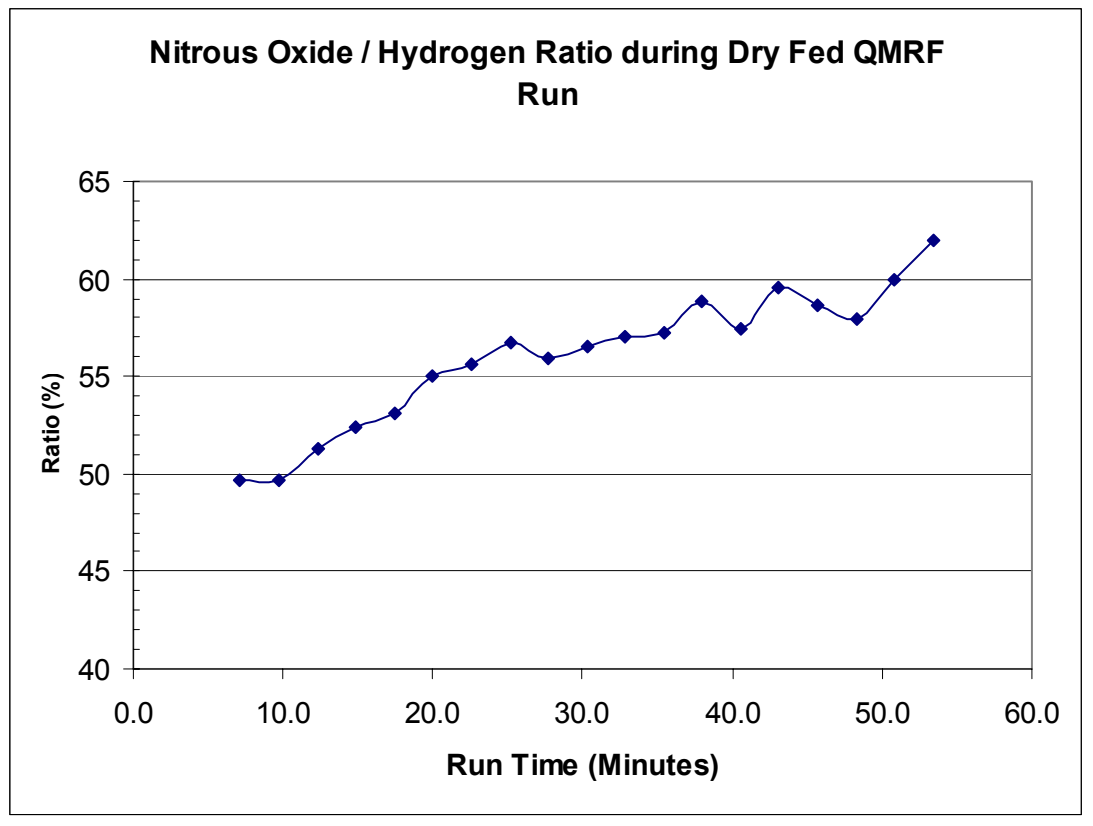

Figure 9. Nitrous Oxide to Hydrogen Ratio during Dry-Fed Tests

Total offgas flow was calculated for each run using the measured helium concentration. The helium concentration was higher than expected during the initial portion of the test when no offgas from the batch is expected. The concentrations were corrected for this offset and the offgas flow for each run is shown in Figure 10. Spikes in the data are likely linked to the noncontinuous nature of the feed cycle and offgas sampling.

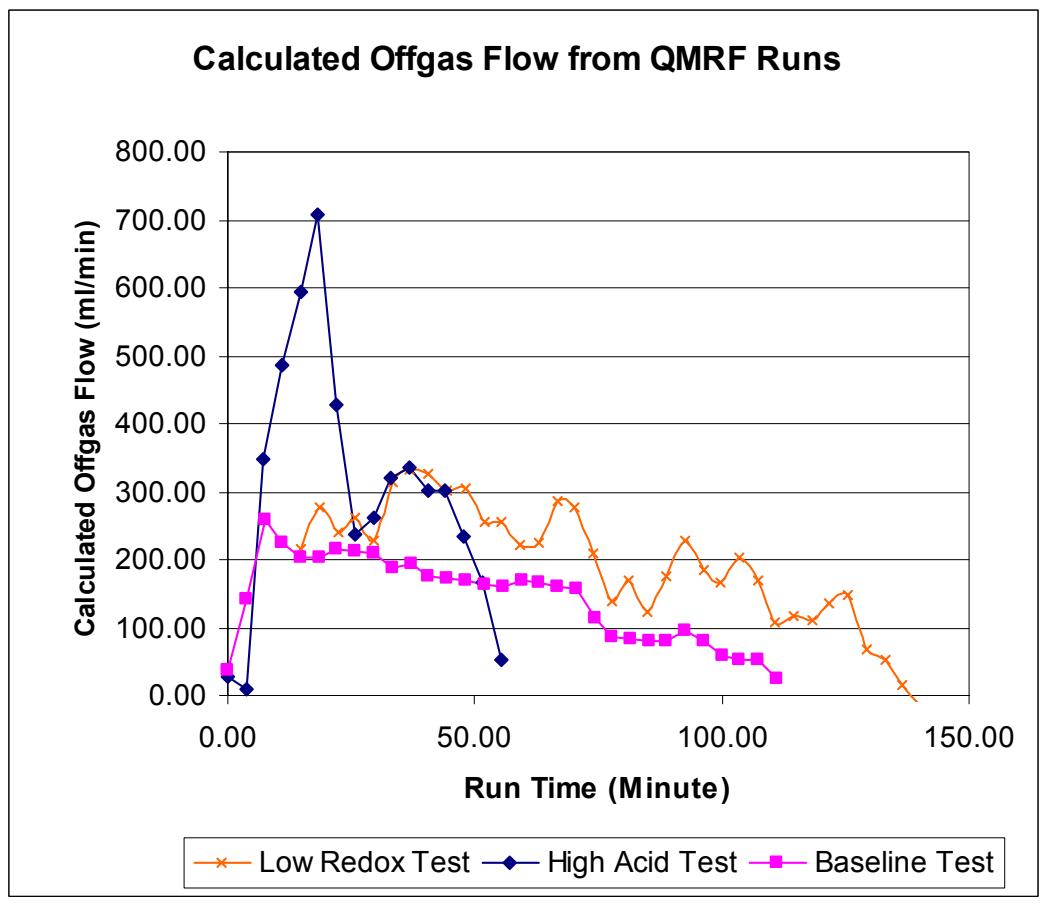

Figure 10. Calculated Offgas Flowrates. 
A nitric oxide (NO) peak was noted during the runs, and a NO concentration is shown on Figure $\mathrm{C}-3$ for the low redox test, but the $\mathrm{GC}$ was not calibrated for this gas and the concentration shown may be inaccurate.

\subsubsection{Overall Summary of Offgas Composition Measurements}

The QMRF was able to measure the composition of the evolved gases from the melter feed during the vitrification process. Differences were noted in the evolved gases from the different batches tested. For example, less hydrogen and more nitrogen was noted during the low redox test versus the baseline and high acid runs as expected due to the shift in the amounts of nitrate and formate expected in the lower redox test. The evaluation of offgas data was hampered by the variation in the data as a function of time, likely a result of the timing of the offgas data samples versus the feed cycle.

Several issues were noted during the runs and modifications to mitigate the issues were developed as discussed below:

$\diamond \quad$ Spikes were noted in offgas composition data.

The spikes may have been related to the pulsed feeding utilized. The gas chromatograph pulls a sample from the offgas line in approximately two minute intervals. The feed cycle operated on nearly the same time cycle. Redesigning the mix tank to allow larger holdup should dampen the cycles and lead to more consistent results.

$\diamond \quad$ Offgas leaks were noted during the runs at several fittings in the offgas line.

Overall offgas composition does not appear to have been impacted. It should be noted that the syringe port was not sealed and allowed some offgas leakage during the runs. Changes in the connections used on the offgas system would likely prevent leaks on future runs.

$\diamond$ Condensate filled the offgas line and led to backpressure.

Changes to condenser configuration would prevent condensate from filling the lines.

$\diamond \quad$ Vapor space temperature was not significantly impacted by feed cycle during offgas composition testing.

Changes to the measurement location and thermocouple size during the melt rate testing discussed below mitigated this problem.

$\diamond$ Solids entrainment into offgas system was very high during the runs as evidenced by the dark coloration of the condensate.

This problem may be related to scale of the tests and may be difficult to mitigate.

\subsection{Melt Rate Tests}

The QMRF was configured in the same manner as the second feed tube test (Figure A-3) and utilized to measure the melt rate of SB3 with Frit 418 [16] and Frit 320 [17]. Feed was produced by combining SB3 SRAT product from previous melt rate testing (FPMR-0021[18]) with the required amounts of Frit 418 and Frit 320. Five thermocouples monitored the beaker 
temperatures during the two runs. The first thermocouple recorded the lid heater temperature and was positioned between the lid heater and the beaker. The second thermocouple was contacting the inside of the beaker bottom. The final three thermocouples were positioned 1", 2", and 4" from the bottom of the beaker. The first segment of the run (45 minutes) was performed with the lid heaters set to 600 watts, then the lid heaters were lowered to 450 watts for the remainder of the run. Feeding was initiated after the furnace reached $1150^{\circ} \mathrm{C}$ and the beaker vapor space reached $750^{\circ} \mathrm{C}$. Approximately $10 \mathrm{ml}$ of feed was added during each feed cycle at a feed rate of $100 \mathrm{ml} / \mathrm{min}$ and lowered the vapor space temperature by varying amounts depending on the position of the thermocouple in the beaker. When the vapor space temperature recovered to $750^{\circ} \mathrm{C}$, the next feed cycle was initiated.

The melt rate was indirectly measured with three methods. All three methods rely on the principle that the faster melting batch would allow the vapor space temperature to recover faster after a feed addition than a slower melting batch. Over time, the amount of feed would be higher for a batch that melts faster. The difference between the methods is how the amount of feed is measured. The first method was the average feed rate over the entire run based on weight of the feed tank. The feed tank weight was recorded at the start and finish of each run with the agitator off. The Frit 320 - SB3 system was run for a longer period of time at the lower lid heater setting, slightly lowering the melt rate determination. The second method involved determining the volume of each feed cycle based on the settings of the peristaltic pump and the time between feed cycles. The feed rate was calculated using this method for each lid heater power setting. This method could have errors if a significant amount of air was entrained into the feed. The third method involved readings from the feed tank weigh scale during the run. The agitator speed affected the readings during the run, therefore adjustments were required to allow the readings to be used when the agitator speed was changed to adjust to different mixing conditions in the feed vessel as the volume was reduced. The measured melt rate results of the two runs are shown in Table 3 and Appendix D. Temperature profiles from the runs are shown in Appendix B.

Table 3. Melt Rate Calculations for Frit 418 and Frit 320 Runs

\begin{tabular}{|l|c|c|c|c|}
\hline \multirow{2}{*}{} & $\begin{array}{c}\text { Frit } \\
418\end{array}$ & $\begin{array}{c}\text { Frit } \\
320\end{array}$ & Units & $\begin{array}{c}\% \\
\text { Difference }\end{array}$ \\
\cline { 2 - 5 } & & & & \\
\hline Initial Feed Tank Weight & 1777.4 & 1776 & grams & \\
\hline Final Feed Tank Weight & 1184 & 1108 & grams & \\
\hline Run Time & 101.65 & 114.45 & $\mathrm{minutes}$ & \\
\hline Average Feed Rate over Entire Run & 5.838 & 5.837 & $\mathrm{~g} / \mathrm{min}$ & 0.0 \\
\hline & & & & \\
\hline 600W Feed Rate - Pump Volume Basis & 6.8 & 6.3 & $\mathrm{~g} / \mathrm{min}$ & 8.3 \\
\hline 450W Feed Rate - Pump Volume Basis & 4.3 & 4.4 & $\mathrm{~g} / \mathrm{min}$ & 3.0 \\
\hline 600W Feed Rate - Weigh Scale Basis & 7.0 & 7.4 & $\mathrm{~g} / \mathrm{min}$ & 4.8 \\
\hline 450W Feed Rate - Weigh Scale Basis & 4.0 & 4.0 & $\mathrm{~g} / \mathrm{min}$ & -0.3 \\
\hline
\end{tabular}

The results indicate that the melt rates for the Frit 320 and Frit 418 cases were essentially equal since the small differences noted in Table 3 are likely within the error of the 
measurement methods. The melt rate results agree with the melt rate measurements from the MRF [19], however, the results do not agree with the tests in the SMRF which indicated that the melt rate using Frit 320 was higher than the melt rate with Frit 418 [20]. Testing in the SMRF has indicated that excessive lid heat power can adversely affect melt rate measurements by overwhelming the impact of the melting batch on the vapor space temperature [21]. The amount of lid heat applied during the QMRF was 600 watts. This level of lid heat may be too large for the melt rate tests and may have affected the QMRF results.

Additional tests must be conducted with the QMRF to determine the sensitivity of the test to melt rate. These tests should be designed to optimize the lid heat power for the QMRF and to test feeds with larger melt rate differences than the two feeds tested. The tests should also be designed to determine the repeatability of the test method. 


\subsection{CONCLUSIONS}

Based on preliminary scoping tests, the QMRF appears to provide insight into offgas and potential melt rate differences for various flowsheets. Further development of this tool would improve the capabilities of the instrument and would lead to an enhanced understanding of the melting process. Differences were noted in the amount of hydrogen relative to carbon dioxide generated during melting of batches at different redox targets, with the lower redox run generating less hydrogen than the baseline or high acid run. This difference was attributed to additional combustion of $\mathrm{CO} / \mathrm{H}_{2}$ mixtures to $\mathrm{CO}_{2} / \mathrm{H}_{2} \mathrm{O}$ during the lower redox run.

The measured melt rates in the QMRF for the SB3 and Frit 418 cases were essentially the same as SB3 and Frit 320. The results from the QMRF test may have been impacted by the amount of lid heat power utilized during the run. Additional runs are required to determine the sensitivity of the QMRF to melt rate and to determine the repeatability of results.

Tests were not conducted that would demonstrate the capability of this instrument to be utilized for radioactive tests. A test plan is under develop to evaluate the capabilities of the instrument for this type of work.

\subsection{RECOMMENDATIONS}

The melt rate performance of the QMRF should continue to be evaluated to determine if it can be used as a screening test for slurry-fed tests. These tests should be designed to optimize the lid heat power for the QMRF and to test feeds with larger melt rate differences than the two feeds tested. The tests should also determine the repeatability of the test method.

The offgas analysis performance of the QMRF should continue to be evaluated and enhanced. The following improvements should be evaluated for incorporation into the apparatus and test protocol:

$\checkmark$ Changes in the connections used on the offgas system to prevent leaks on future runs.

$\diamond$ Redesign of mix tank to dampen offgas surges and provide more consistent composition data.

$\diamond$ Changes to the condenser configuration to prevent condensate from filling the lines.

$\diamond \quad$ Evaluate higher purge rates into the beaker.

Evaluation of sampling the offgas data from the condenser exit to eliminate the smoothing effect of the tank and to allow the offgas composition profile to be measured for each feed cycle should be evaluated.

A plan should be developed and implemented to allow the QMRF to be utilized to determine the melt rate of radioactive feeds. 


\subsection{REFERENCES}

1. Smith, M. E. , et al, The Impact of Feed Preparation Acid Stoichiometry and Redox on Melt Rate for the SB3-Frit 418 Feed System, WSRC-TR-2004-00350, July 2004.

2. Technical Task Request, HLW-DWPF-TTR-03-0016, 8/11/03.

3. Task Technical and QA Plan, Investigation of Slow Melting Cold Cap Chemistry and Chemical Improvements to Improve Melt Rate, WSRC-RP-2003-01033, 12/8/03.

4. Stone, M. E., Run Plan for Initial Dry Feed Tests in the Quartz Beaker Melt Rate Furnace (U), SRT-GPD-2004-00004, January 13, 2004.

5. WSRC-NB-2003-00226, DWPF Support Laboratory Notebook

6. Smith, M. E. , et al, The Impact of Feed Preparation Acid Stoichiometry and Redox on Melt Rate for the SB3-Frit 418 Feed System, WSRC-TR-2004-00350, July 2004.

7. Stone, M. E., Run Plan for Feed Tube Tests in the Quartz Beaker Melt Rate Furnace (U), SRT-GPD-2004-00009, January 30, 2004.

8. Stone, M. E., Run Plan for Feed Tube Tests with Lid Heaters in the Quartz Beaker Melt Rate Furnace (U), SRT-GPD-2004-00045, April 12, 2004.

9. Stone, M. E., Run Plan for Baseline Slurry-Fed Quartz Beaker Melt Rate Furnace (U), SRT-GPD-2004-00063, May 4, 2004.

10. Smith, M. E., et al, The Impact of Feed Preparation Acid Stoichiometry and Redox on Melt Rate for the SB3-Frit 418 Feed System, WSRC-TR-2004-00350, July 2004.

11. Stone, M. E., Run Plan for 0.0 Redox Slurry-Fed Quartz Beaker Melt Rate Furnace (U), SRNL-GPD-2004-00011, July 12, 2004.

12. Smith, M. E., et al, The Impact of Feed Preparation Acid Stoichiometry and Redox on Melt Rate for the SB3-Frit 418 Feed System, WSRC-TR-2004-00350, July 2004.

13. Stone, M. E., Run Plan for $185 \%$ Acid Slurry-Fed Quartz Beaker Melt Rate Furnace (U), SRNL-GPD-2004-00012, July 12, 2004.

14. Smith, M. E. , et al, The Impact of Feed Preparation Acid Stoichiometry and Redox on Melt Rate for the SB3-Frit 418 Feed System, WSRC-TR-2004-00350, July 2004.

15. Choi, A. S., Validation of DWPF Melter Off-Gas Combustion Model, WSRC-TR-200000100, June 23, 2000.

16. Miller, D. H., Run Plan for Slurry Feeding SB3 with Frit 418 in the Melt Rate Furnace, SRNL-GPD-2004-00023, August 16, 2004.

17. Miller, D. H., Run Plan for Slurry Feeding SB3 with Frit 320 in the Melt Rate Furnace, SRNL-GPD-2004-00024, August 16, 2004.

18. Miller, D. H., Summary of Recent MRF Testing on SB2/3, SRNL-GPD-2004-00010, July 7, 2004.

19. Miller, D. H., Summary of Recent MRF Testing on SB2/3, SRNL-GPD-2004-00010, July 7, 2004.

20. Smith, M. E., et al, Slurry-Fed Melt Rate Furnace Tests for the SB3 Frit 320 Feed System (U), WSRC-TR-2004-00459, September 2004.

21. Smith, M. E., et al, SMRF and MRF DWPF Melt Rate Testing for SB2/SB3 (Case 6B 250 Canisters) (U), WSRC-TR-2003-00466, October 30, 2003. 
WSRC-TR-2004-00464

Revision 0

\section{Appendix A. Diagrams of QMRF Configurations}




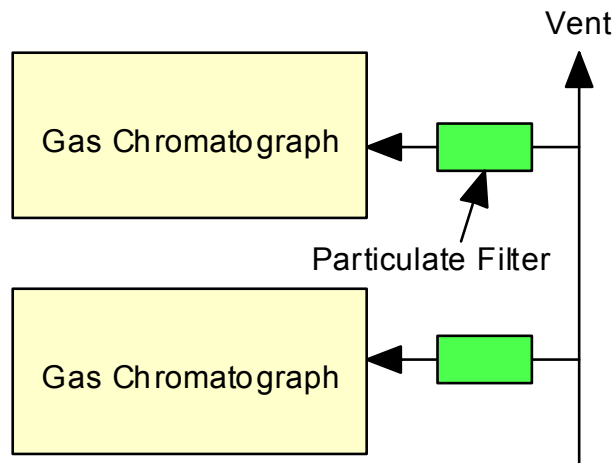

Dilution Ar-O2: $2000 \mathrm{ml} / \mathrm{min}$

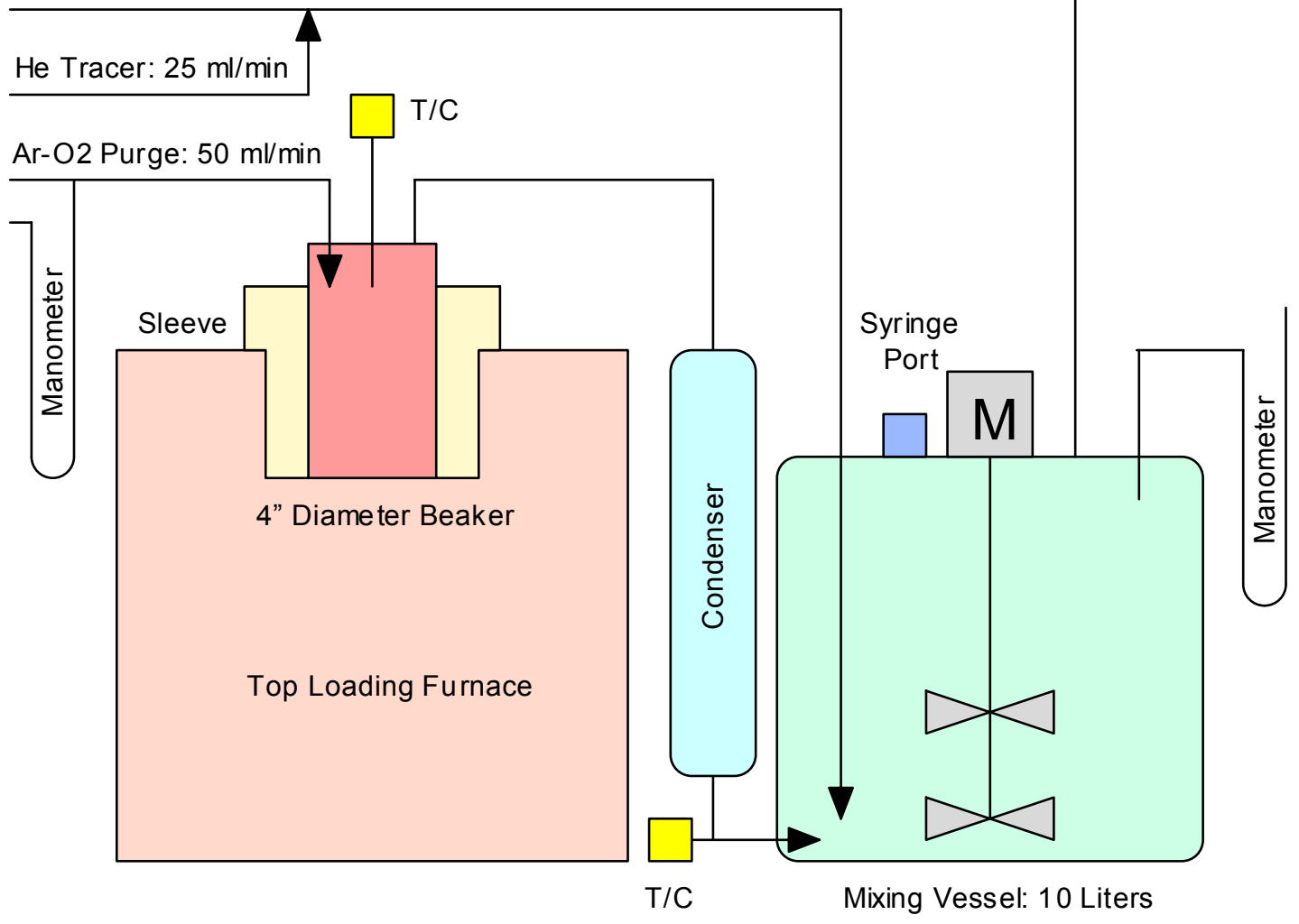

Figure A-1. QMRF for Initial Dry-Fed Test 
WSRC-TR-2004-00464

Revision 0

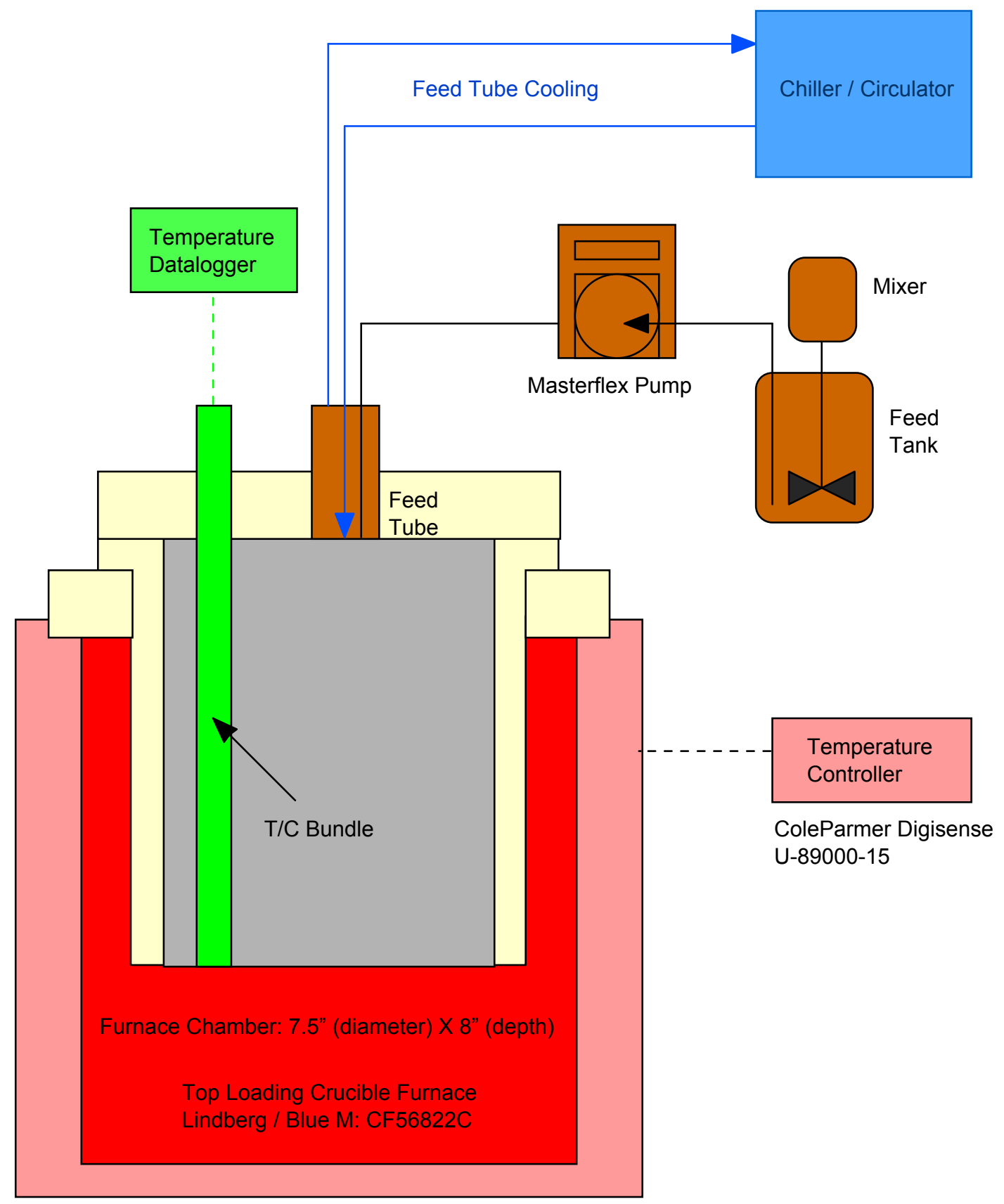

Figure A-2. QMRF Configuration for Initial Feed Tube Test 
WSRC-TR-2004-00464

Revision 0

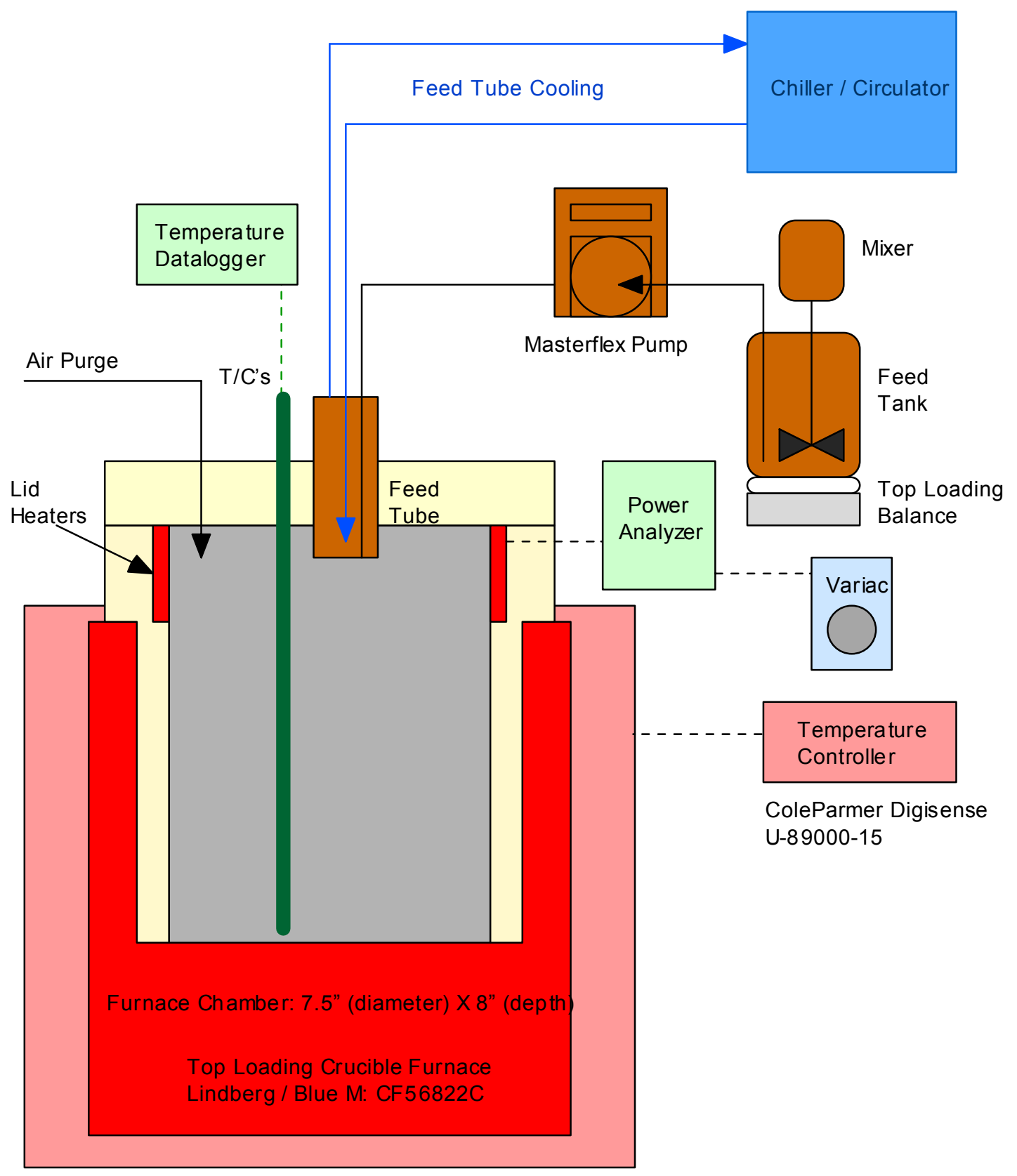

Figure A-3. QMRF Configuration for Second Feed Tube Test 


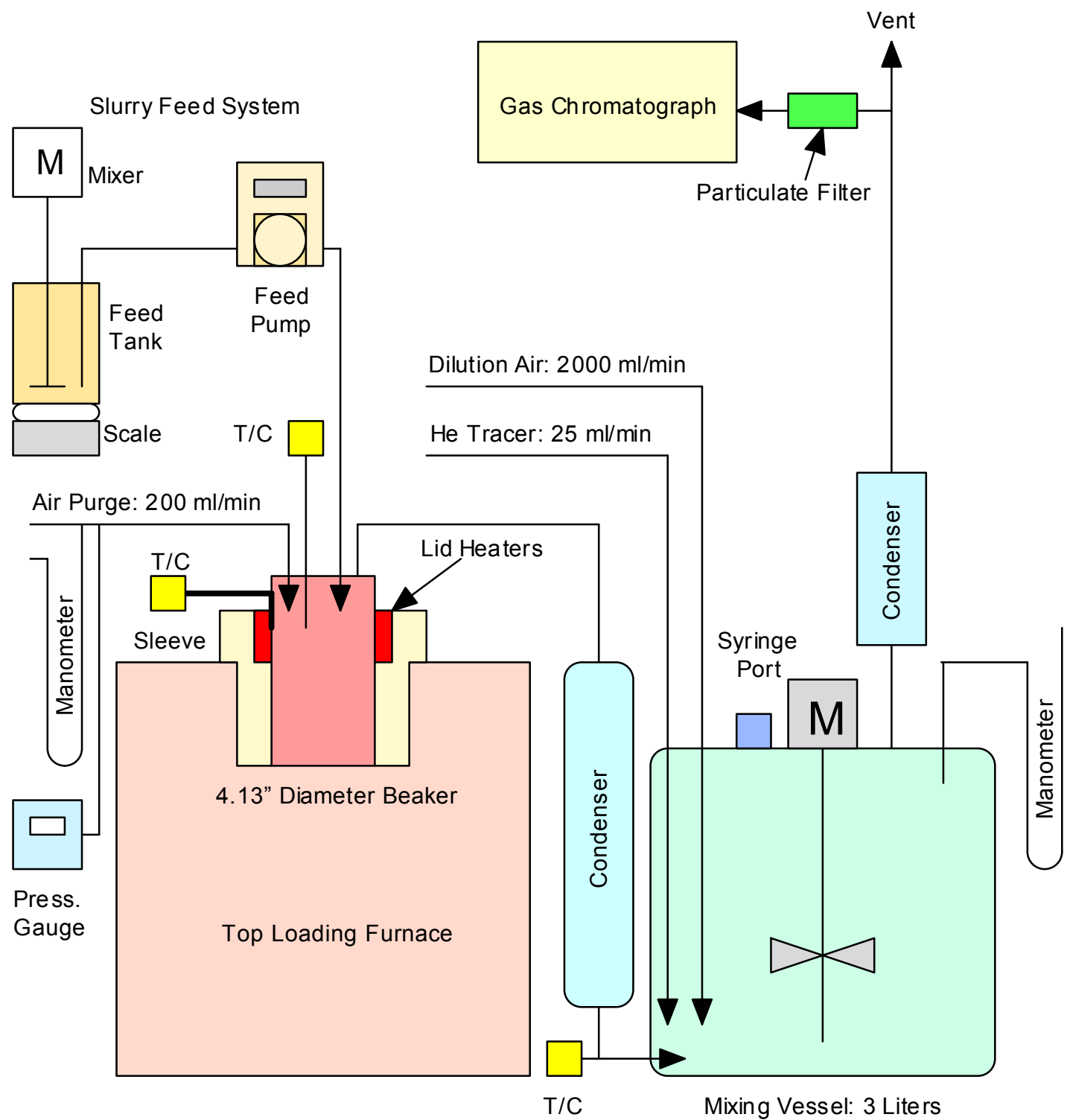

Figure A-4. QMRF Configuration for Baseline, Low Redox, and High Acid Tests 
WSRC-TR-2004-00464

Revision 0

Appendix B. Temperature Data from QMRF Runs 


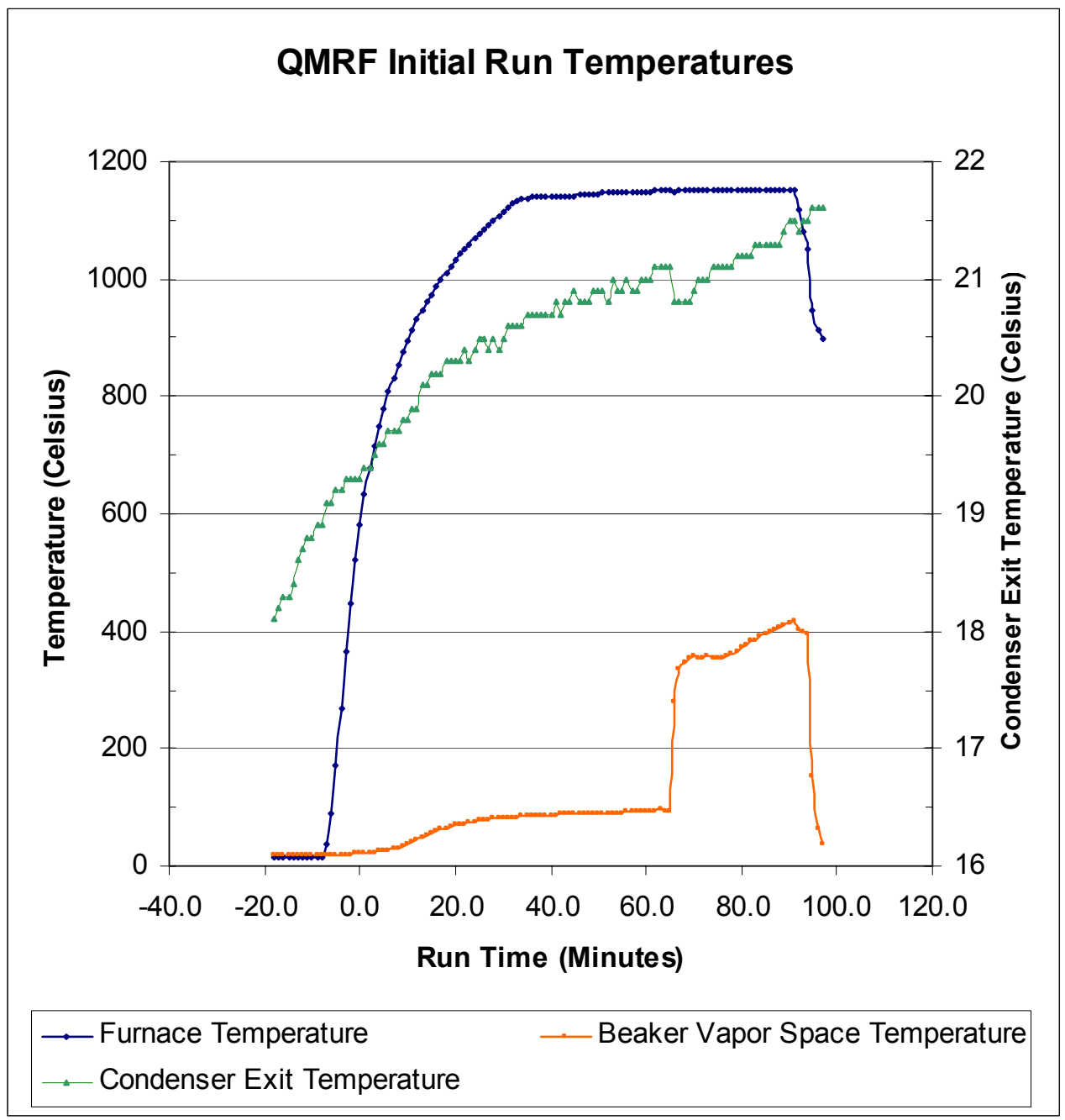

Figure B-1. Temperature Profiles during Initial Dry-Fed QMRF Run 


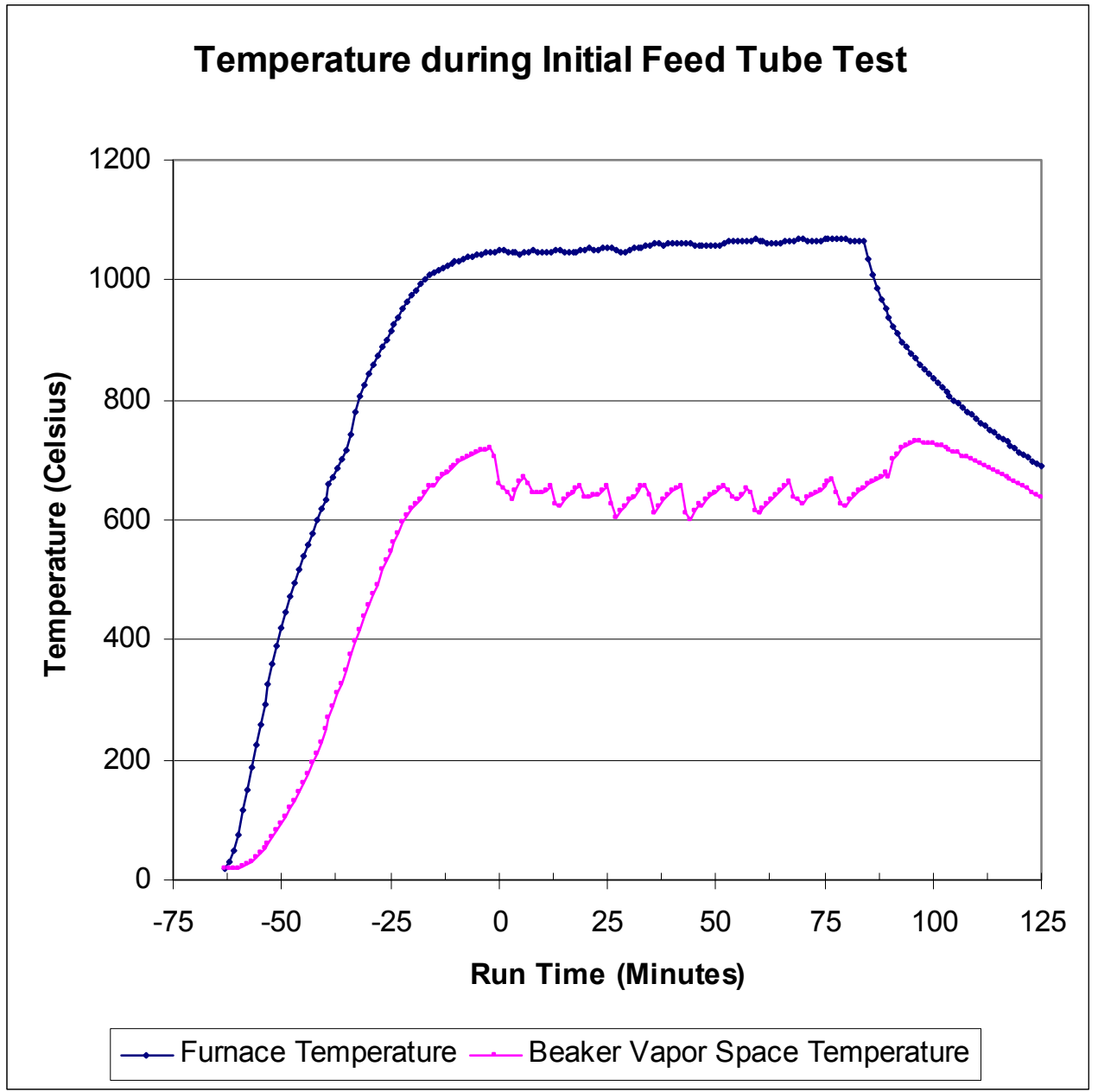

Figure B-2. Temperature Profile during Initial Feed Tube Tests 


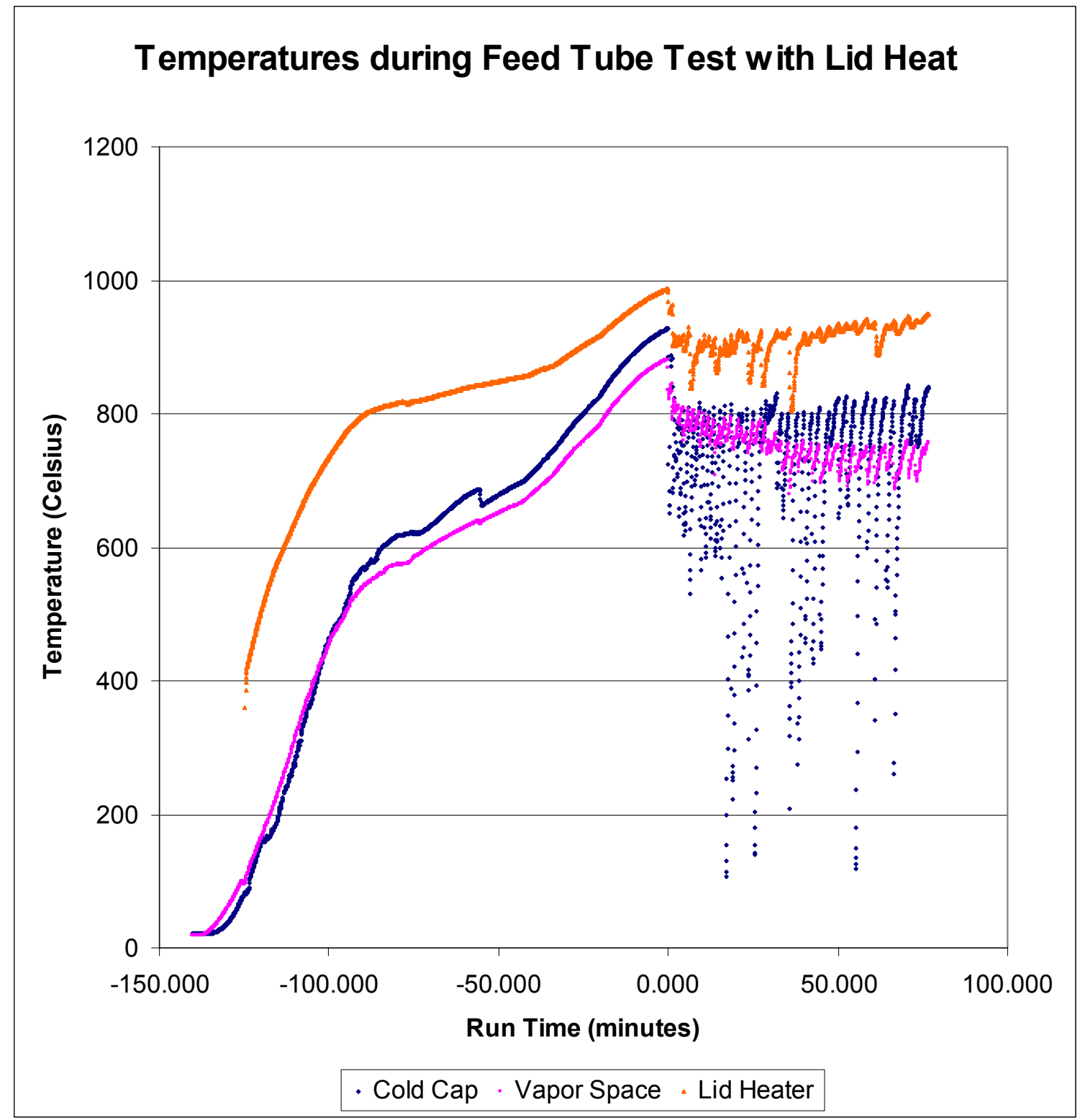

Figure B-3. Temperature Profile during Feed Tube Test with Lid Heat 
WSRC-TR-2004-00464

Revision 0

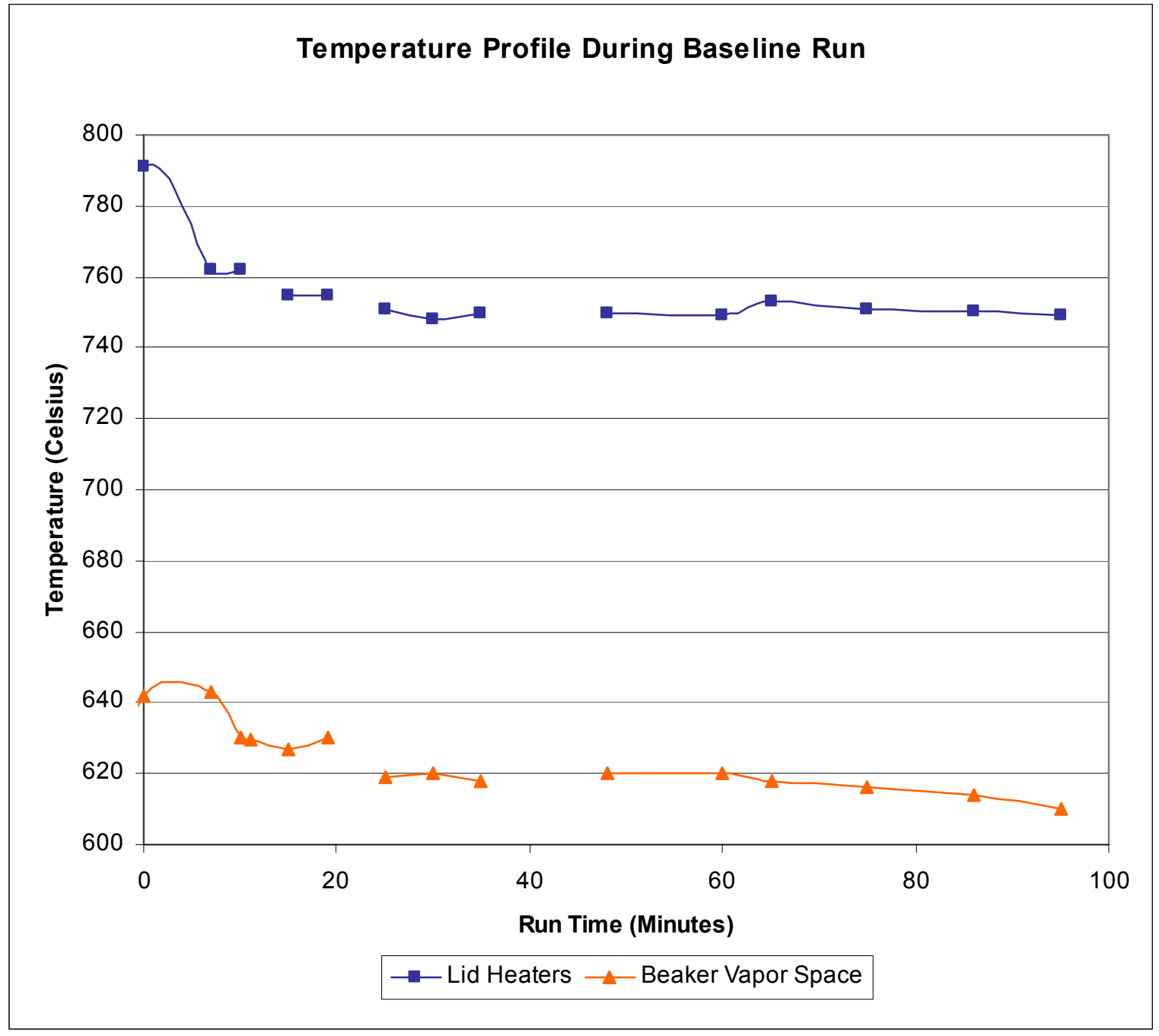

Figure B-4. Temperature Profile during Baseline Run (Manual Temperature Readings) 


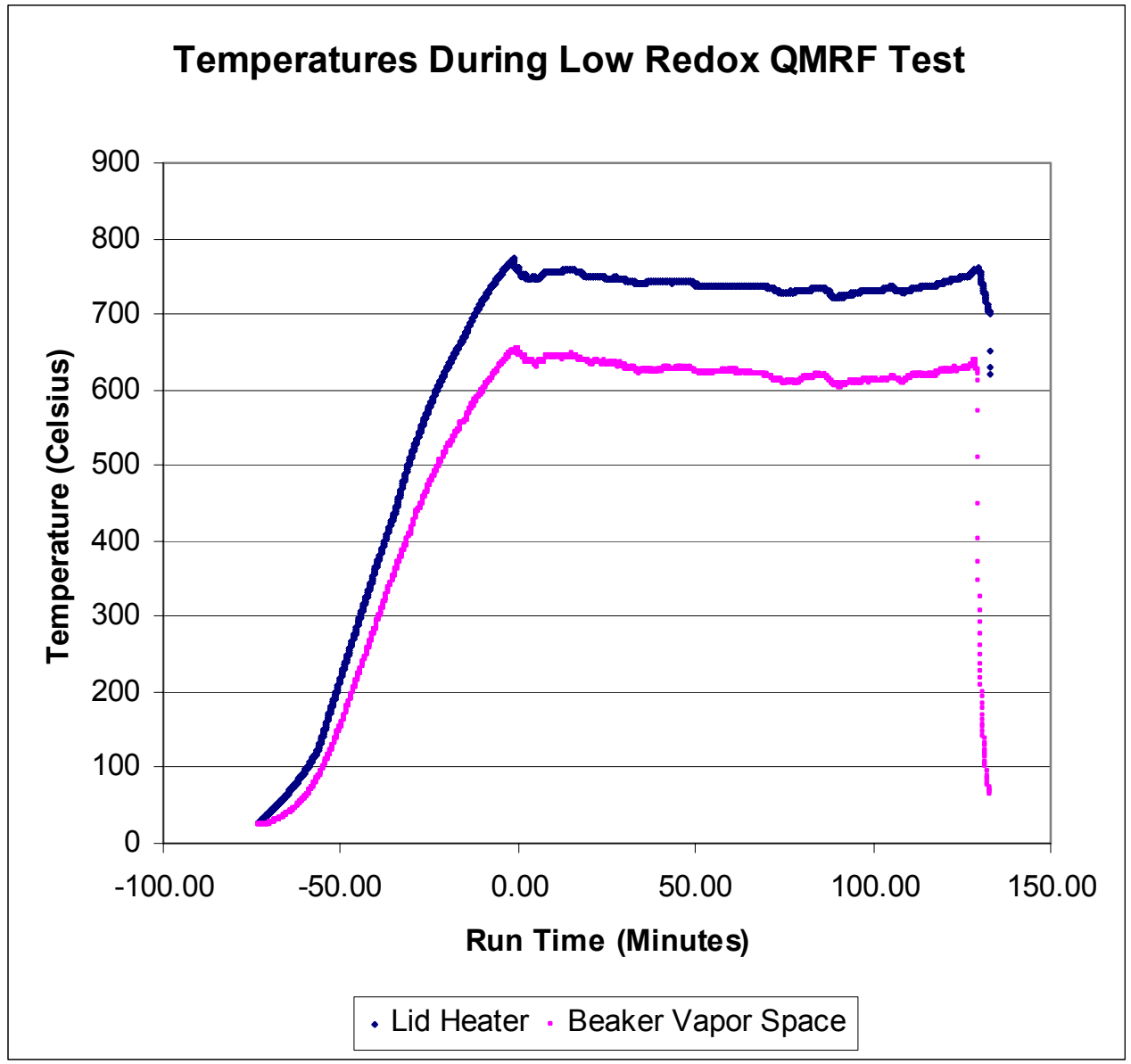

Figure B-5. Temperature Profile during Low Redox QMRF Run. 


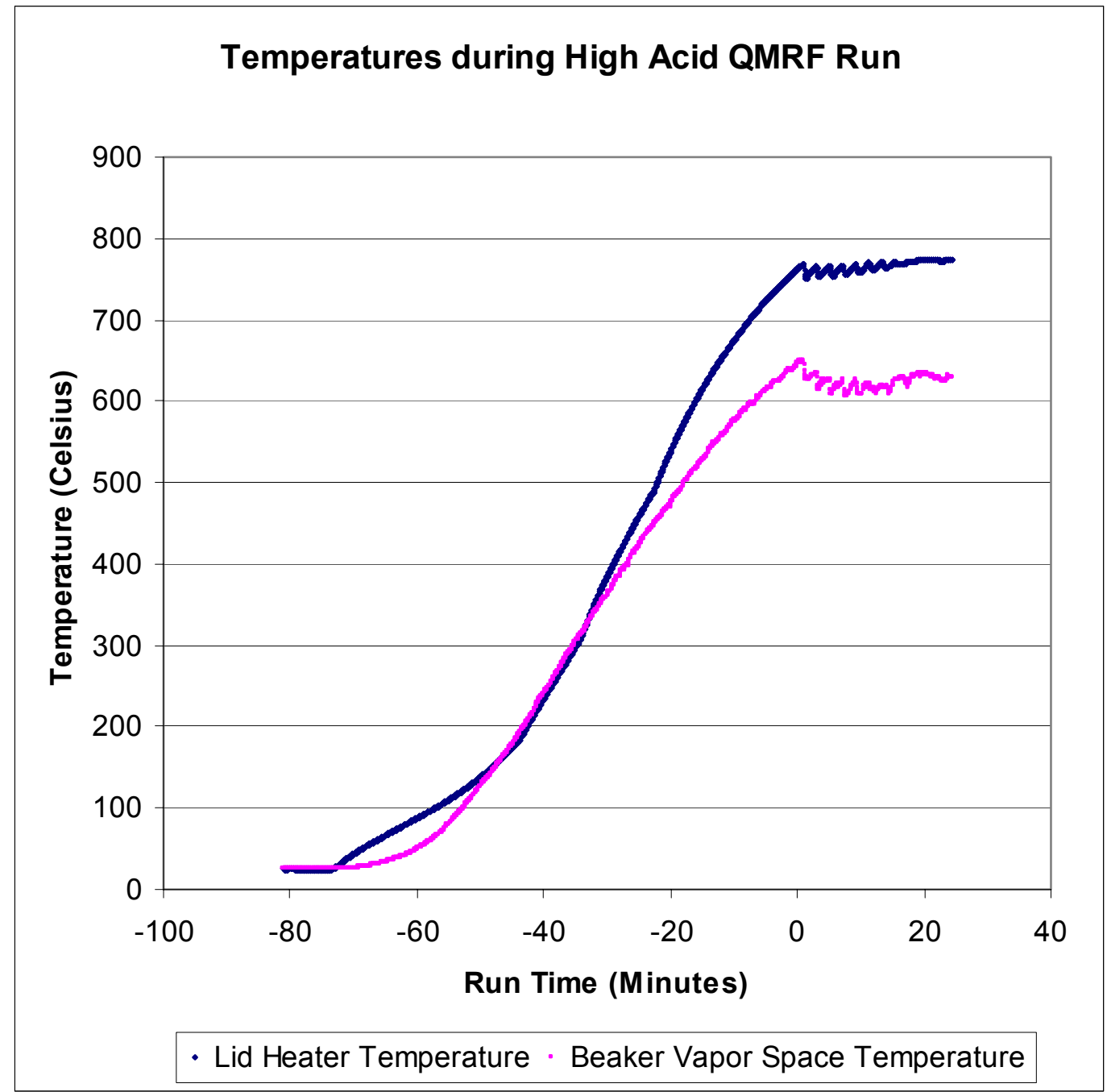

Figure B-6. Temperature Profile during High Acid QMRF Run. 


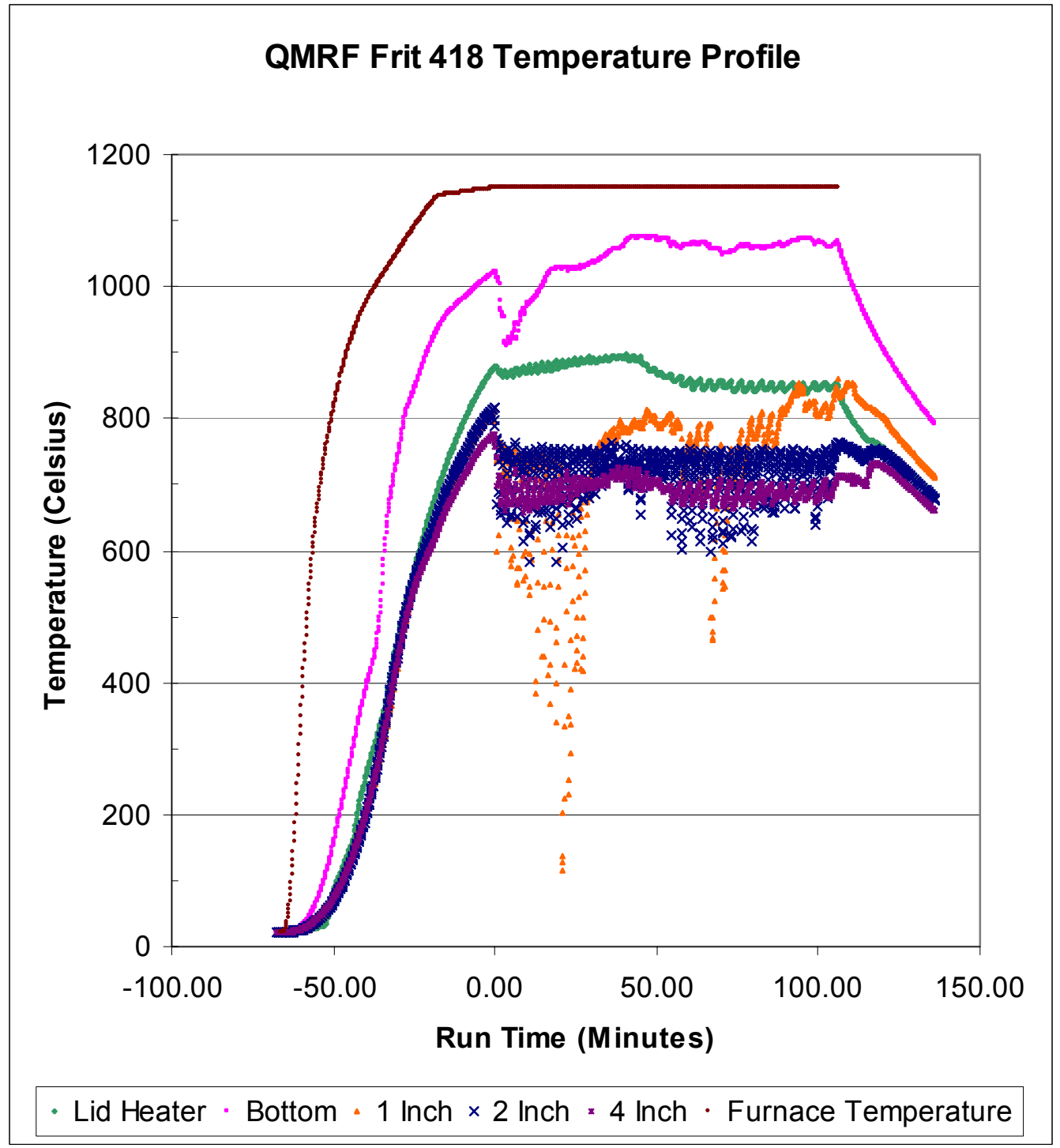

Figure B-7. Temperature Profile during Frit 418 Melt Rate Test 


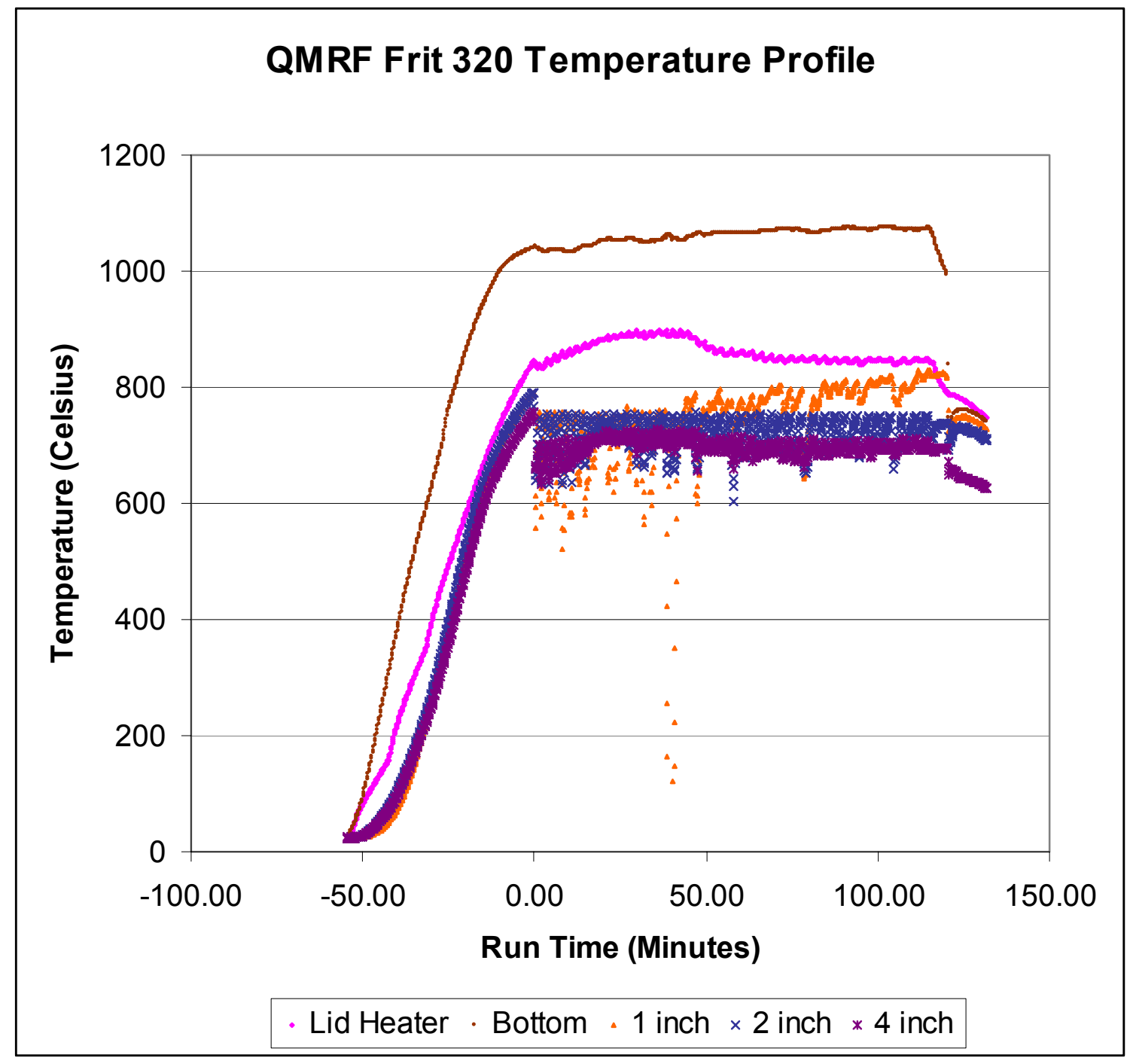

Figure B-8. Temperature Profile during Frit 320 Melt Rate Test 
WSRC-TR-2004-00464

Revision 0

Appendix C. Gas Chromatograph Data from QMRF Runs 


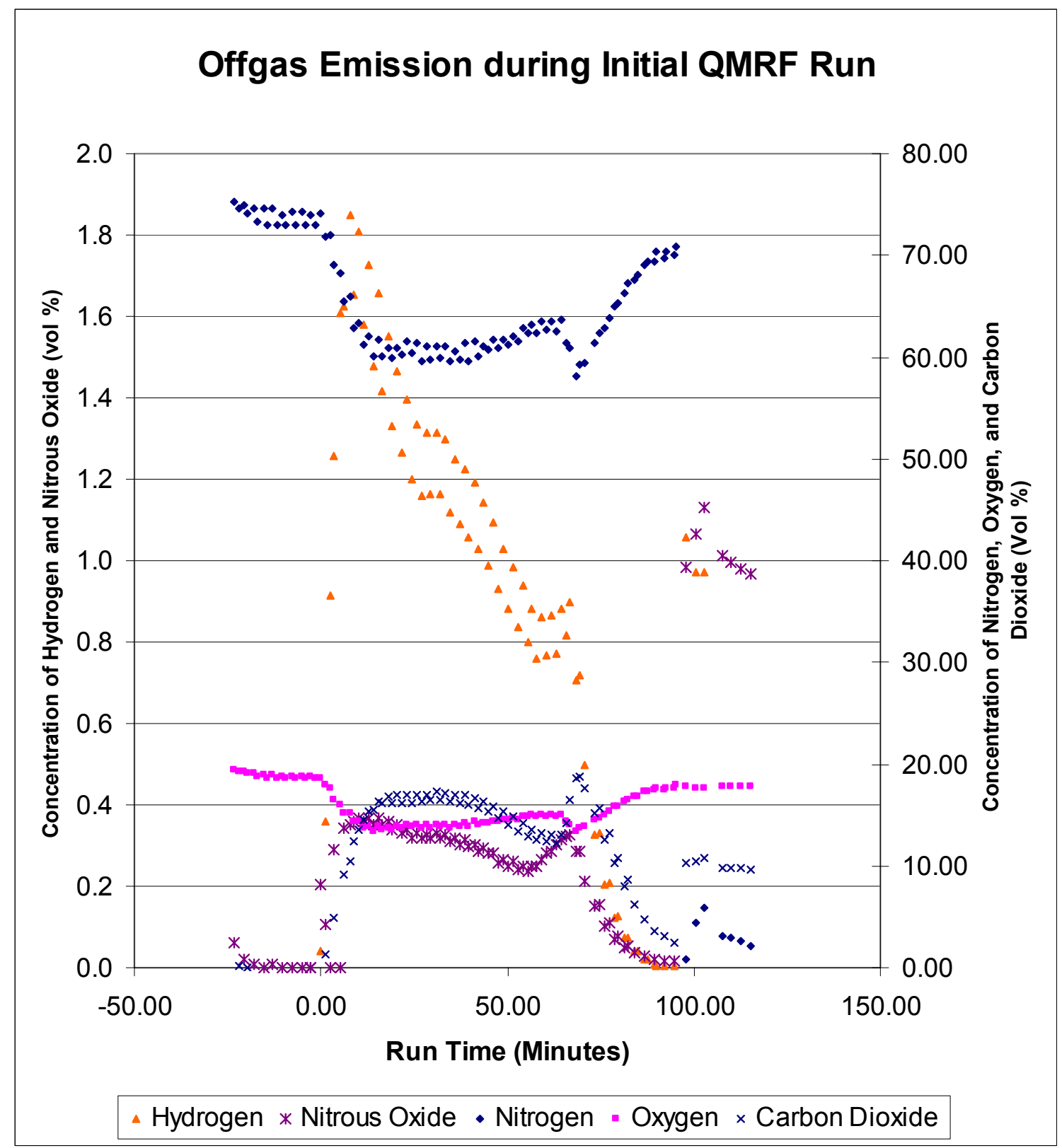

Figure C-1. Offgas Composition Data from Initial Dry-Fed QMRF Run. 


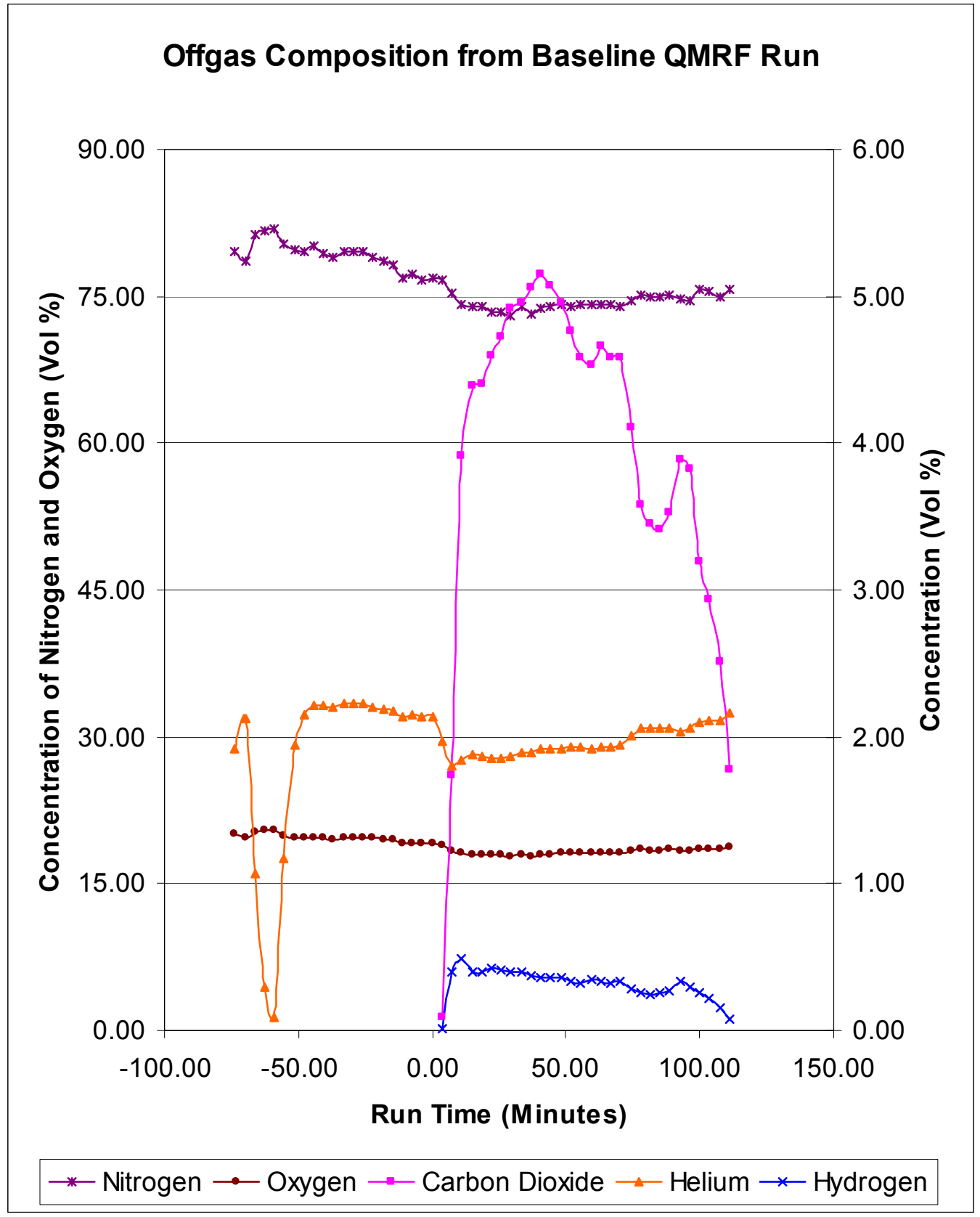

Figure C-2. Offgas Data from Baseline QMRF Run. 


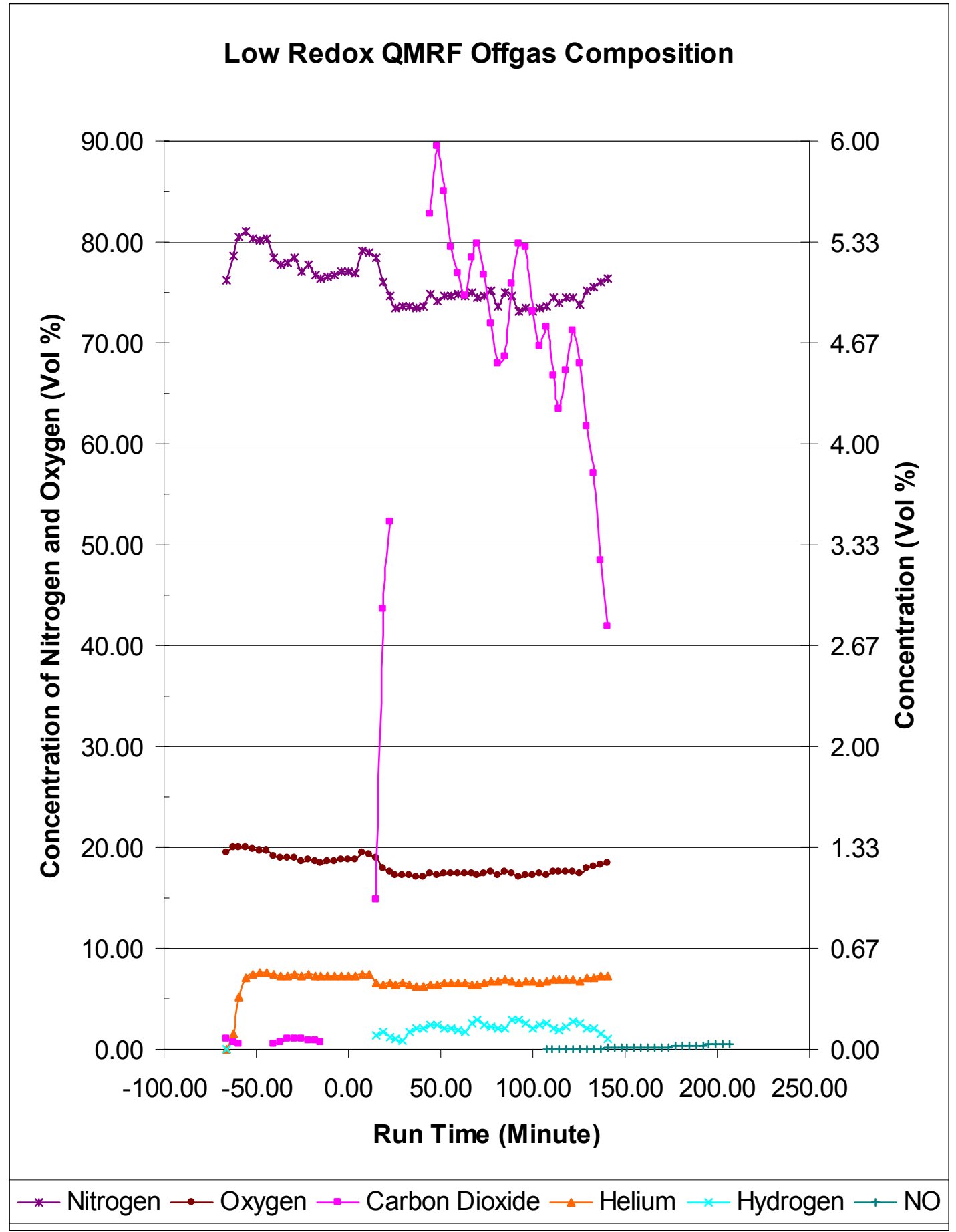

Figure C-3. Offgas Composition Data from Low Redox QMRF Run 


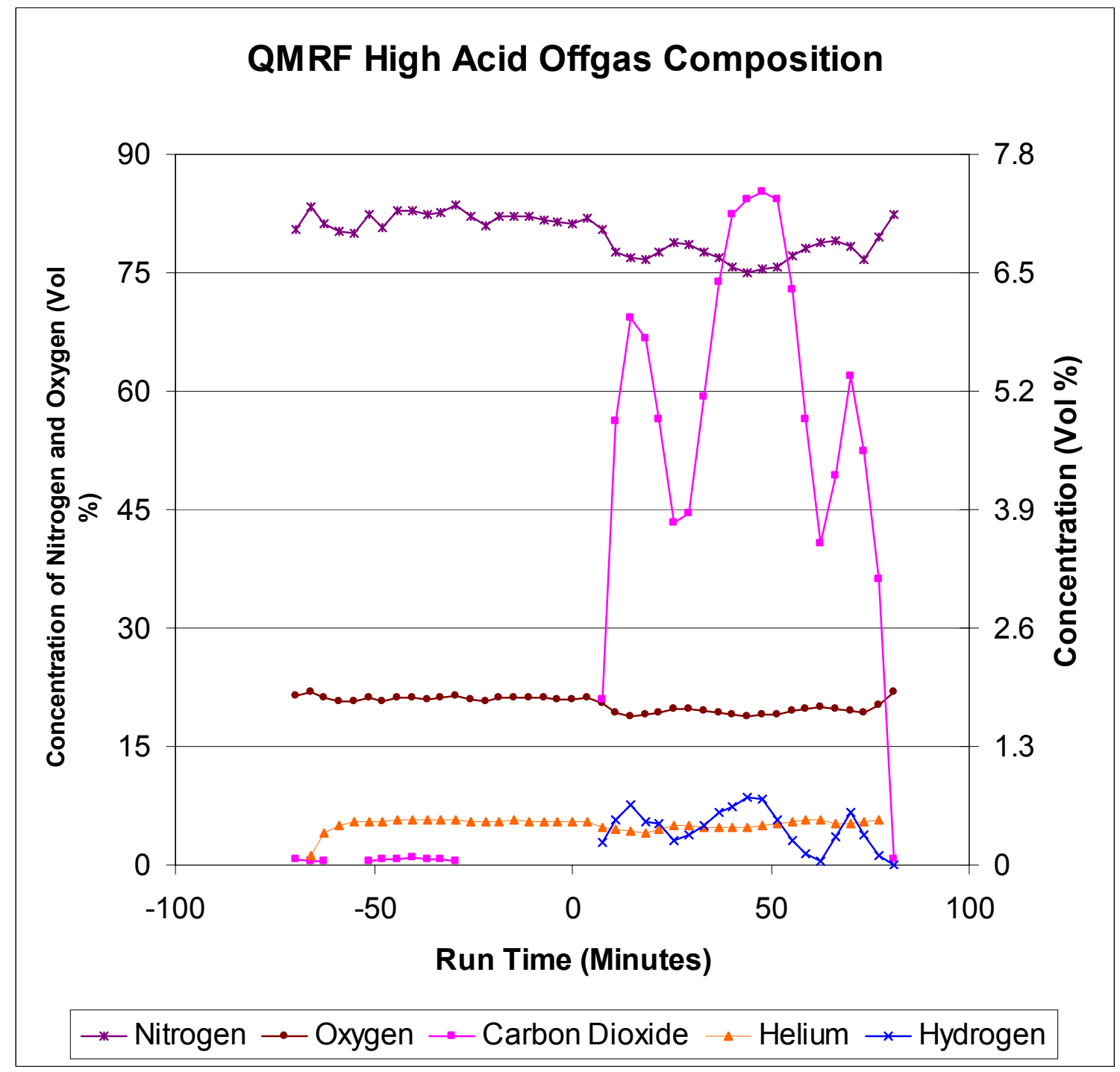

Figure C-4. Offgas Composition Data from High Acid QMRF Run 
WSRC-TR-2004-00464

Revision 0

Appendix D. Feed Rate Charts for Melt Rate Tests 


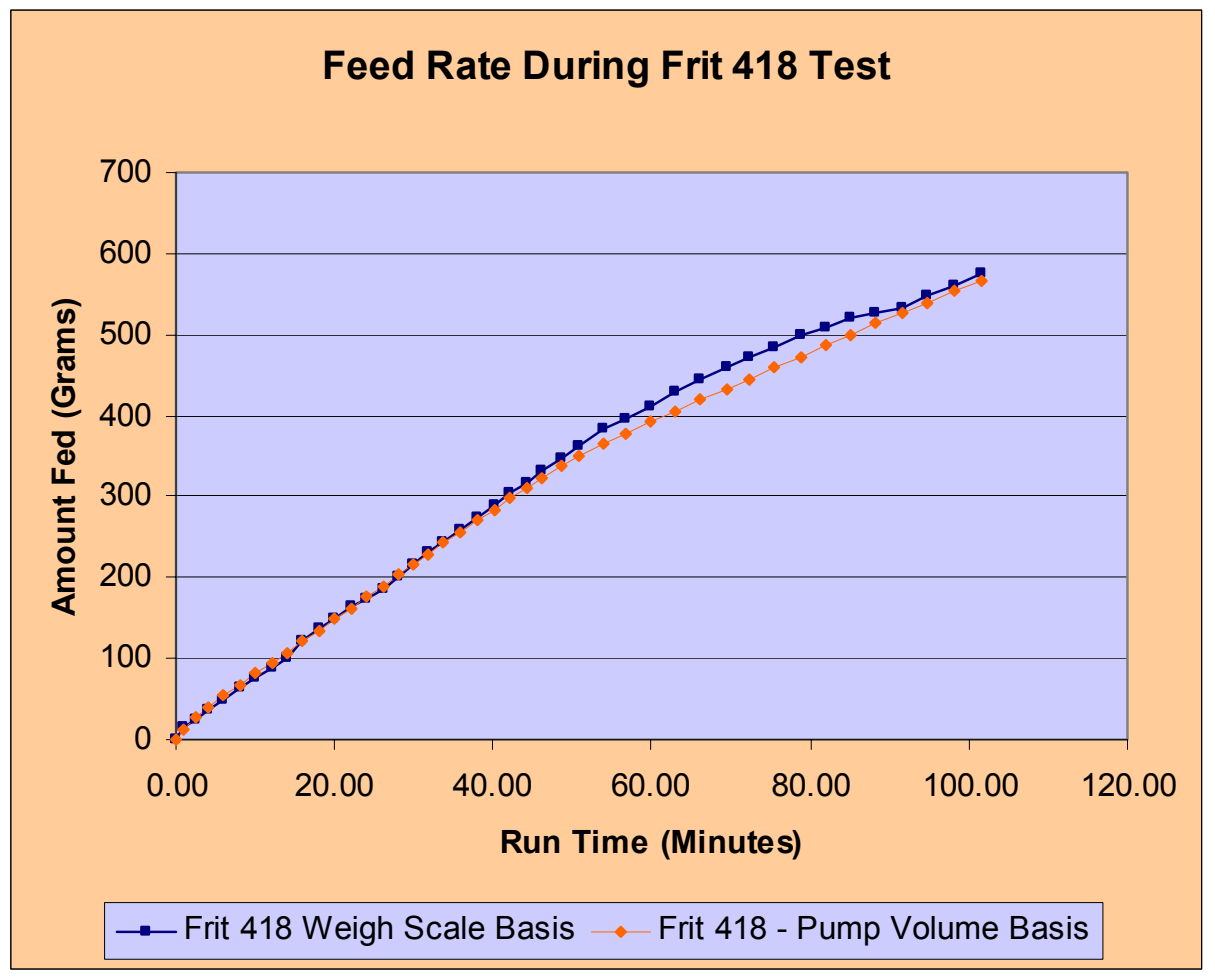

Figure D-1. Feed Rate Chart for Frit 418

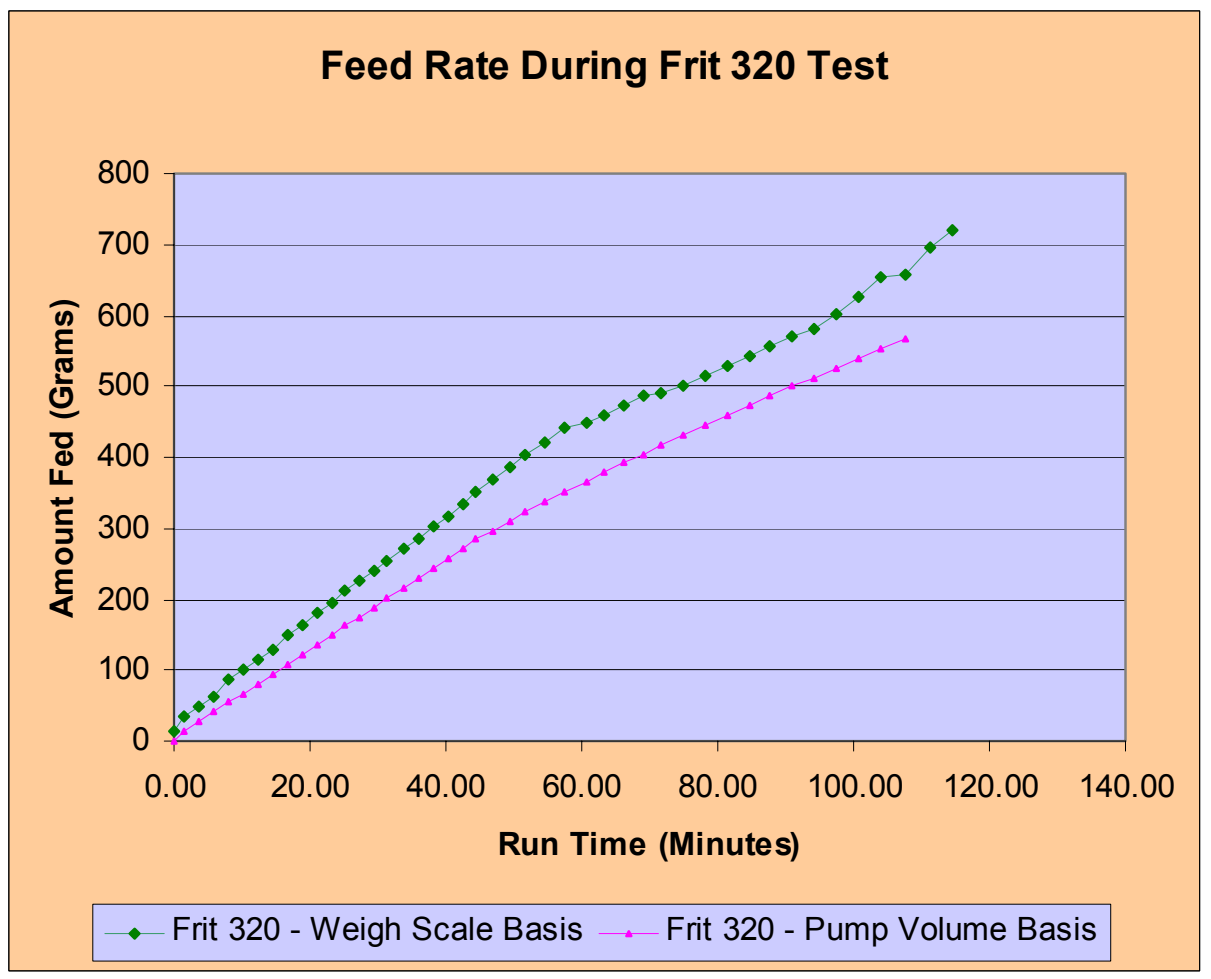

Figure D-2. Feed Rate Chart for Frit 320 